\title{
MANAGEMENT OF THE TRAINING PROCESS OF MILITARY PILOTS BASED ON THE ANALYSIS AND ASSESSMENT OF FLIGHT PARAMETERS FROM ON-BOARD RECORDERS
}

\section{ZARZĄDZANIE PROCESEM SZKOLENIA PILOTÓW WOJSKOWYCH NA PODSTAWIE ANALIZY I OCENY PARAMETRÓW LOTU Z REJESTRATORÓW POKŁADOWYCH}

\author{
Mariusz Zieja Henryk Smoliński , Pawel Gołda
}

Air Force Institute of Technology, Instytut Techniczny Wojsk Lotniczych

e-mails:mariusz.zieja@itwl.pl,pawel.golda@itwl.pl

\begin{abstract}
The main and unchangeable principle of aviation activities is to preserve the conditions for safe flying. In present conditions, in constantly growing tasks, aviation requires organizational and methodological treatments at the highest quality. Article is devoted to the analysis of parametric information accumulated through on-board storage media registration of flight data. The article presents selected examples of methods and tools to analyze data and identify corrective and I or preventive actions, which help to increase the effectiveness and efficiency of the entire process of flight training. Conducted in the article discussion and examples highlight the important role of objective flight control as a tool for continuous monitoring of the level of security of performed air tasks in terms of piloting techniques and technical efficiency of the aircraft.
\end{abstract}

Keywords: flight safety, flight safety management, flight training

Streszczenie: Główna i niezmienna zasada lotniczej działalności jest zachowanie warunków bezpiecznego latania. $W$ obecnych warunkach, stale rosnacych zadań lotnictwo wymaga najwyższej jakości zabiegów organizacyjnych i metodologicznych. Artykut poświęcony jest analizie informacji parametrycznych nagromadzonych za pomoca pokładowych nośników rejestracji danych z lotu. $W$ artykule przedstawiono przykłady wybranych metod $i$ narzędzi do analizy danych $i$ identyfikacji czynności korygujacych i/lub zapobiegawczych, które postużyć maja podniesieniu skuteczności i efektywności calego procesu szkolenia lotniczego. Przeprowadzone w artykule rozważania i przyklady zwracaja uwage na ważna rolę obiektywnej kontroli lotów jako narzędzia statego monitorowania poziomu bezpieczeństwa wykonywanych zadań lotniczych pod katem techniki pilotowania oraz sprawności technicznej statków powietrznych.

Słowa kluczowe: bezpieczeństwo lotów, zarządzanie bezpieczeństwem lotów, szkolenie lotnicze 
Management of the training process of military pilots ...

Zarzadzanie procesem szkolenia pilotów wojskowych...

\section{MANAGEMENT OF THE TRAINING PROCESS OF MILITARY PILOTS BASED ON THE ANALYSIS AND ASSESSMENT OF FLIGHT PARAMETERS FROM ON-BOARD RECORDERS}

\section{Introduction}

Information recorded by flight parameter on-board recorders can be used after its playback for different purposes (Figure 1). The first of them includes an operational analysis. It is primarily used to detect dangerous flight phases, which is usually associated with the exceeding of critical values of most important flight parameters or their unfavourable combination. For each aircraft type, it is a collection of dozens of algorithms, the scope of which can be broadly divided into two categories. The first category of algorithms directly relates to the performed flight operation safety. The detection of the exceeding in this category means the necessity to take further action by the flight security service. It can be an additional aircraft inspection after hard landing and exceeding of permissible flight velocities, appropriate loads, engine parameters, etc. The analysis of such a case is carried out by people associated with the technical service, as well as people from the area of aviation safety and flight training methodology.

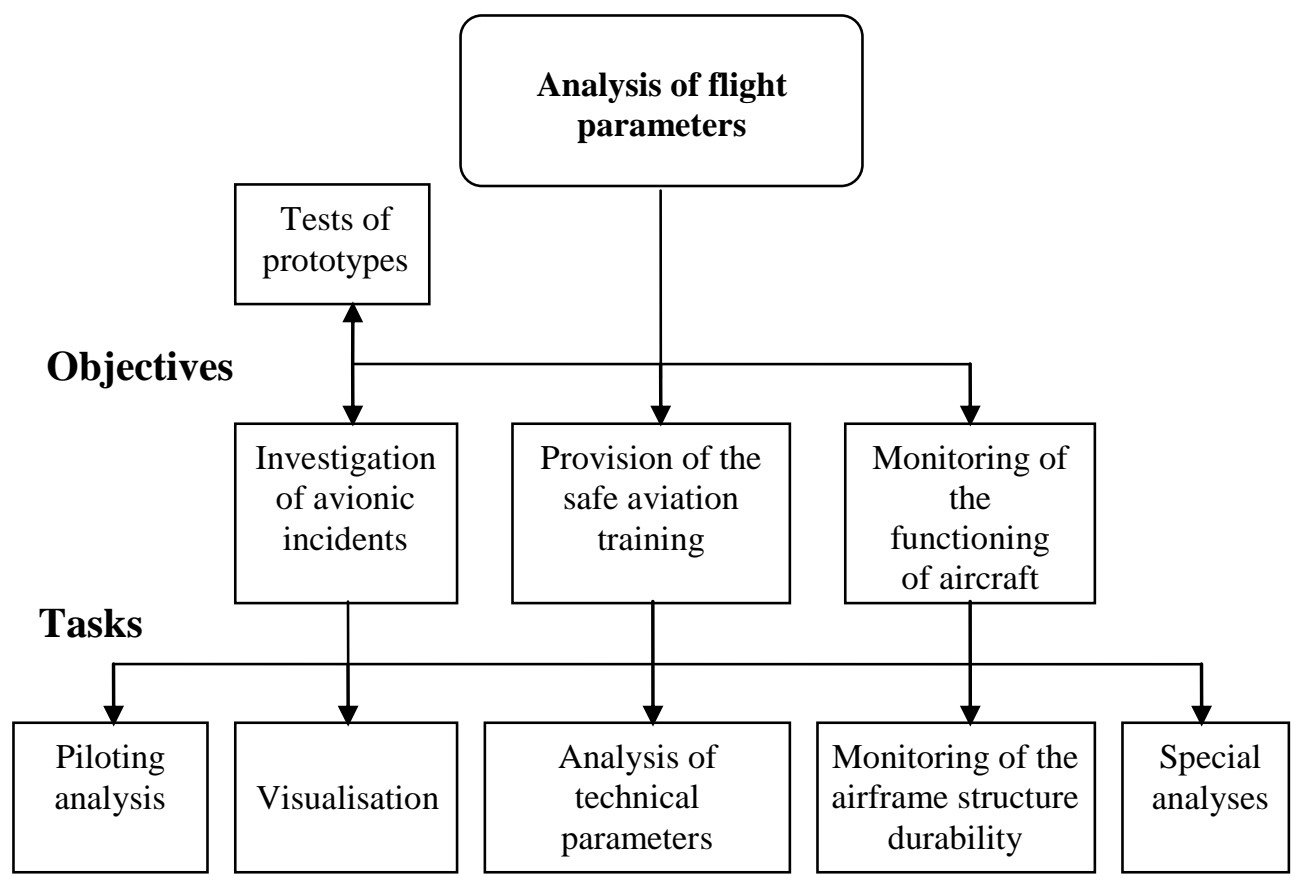

Fig. 1. Functional diagram of the analysis of flight parameters in military aviation 
Engineering services check the aircraft condition after the occurrence of exceeding, and specialists on the piloting technique conduct preventive and methodical activities among the aviation personnel.

The second category includes typical piloting excess, the effects of which have a secondary impact on the aircraft operational condition and are associated with aircraft piloting failures, as well as too large deviations in landing approach routes or aircraft incorrect configuration in various flight states.

The violation of the safe operation execution rules also constitutes flight states close to extension or too fast approaching to the ground. This exceeding (as opposed to the first one) does not have a direct impact on deterioration of aircraft properties, however, they can also lead to the occurrence of very dangerous flight states, and finally to a crash. Such cases are analysed by the flight security service and flight training service [2], [4], [5], [6], [7].

\section{Analysis of Mig-29 aircraft flight during the performance of piloting figures}

The analysis of Mig-29 aircraft piloting figures on the basis of actual records from on-board data recording devices during flight was carried out for the 19th exercise of the Combat Training Programme of Fighter Aviation [Program Szkolenia Bojowego Lotnictwa Myśliwskiego] performed by pilots of various training susceptibility [3].

The exercise No. 19 according to the Combat Training Programme of Fighter Aviation consists of piloting elements, the proper performance of which is one of more complex activities in the piloting area.

During the flight, the following activities are performed:

- Start at the afterburning with the performance of Immelman turn (optionally)

- Climbing turn at the afterburning at the altitude of $1000 \mathrm{~m}$;

- Lowering to the altitude of $500 \mathrm{~m}$;

- Climbing turn within the engine's operating maximum range;

- Lowering to the altitude of $200 \mathrm{~m}$;

- Turns of 90 degrees with the tilt of $45^{0}$;

- Acceleration to the speed necessary for the introduction to the pull-up;

- Pull-up at an angle of $45^{\circ}$;

- Diving at an angle of $45^{\circ}$;

- Combat turn (by loop curve);

- Half-turn with leading to the loop curve;

- Half-turn with leading to the horizontal flight;

- Curved loop with leading to the horizontal flight;

- Combat turn;

- Stall turn with leading to the horizontal flight;

- Loop with leading to the horizontal flight;

- Immelman;

- Circuit landing at the altitude of $200 \mathrm{~m}$. 
Management of the training process of military pilots ...

Zarzadzanie procesem szkolenia pilotów wojskowych...

The analysis of piloting figures included flights, which were performed within the framework of the aviation training process in the following conditions:

- The number of flights during the training period -2 .

- Flight time - 30 min.

- Exercise purpose: Teach (check) the pilot in terms of the performance of medium flight manoeuvres at low altitudes.

- Performance conditions: usual weather conditions with the natural horizon visibility.

- Altitude range: $500-3500 \mathrm{~m}$.

The comparative analysis was carried out on the basis of materials from the the objective control of flights for 3 pilots with various degrees of assimilation of piloting habits. (Fig.2. - Fig.16.)

The markings of parameters occurring in materials from the objective flight control and subject to decryption with the use of THETYS IV system in the objective flight control system (Aviation Training Centre) were presented in Table 1.

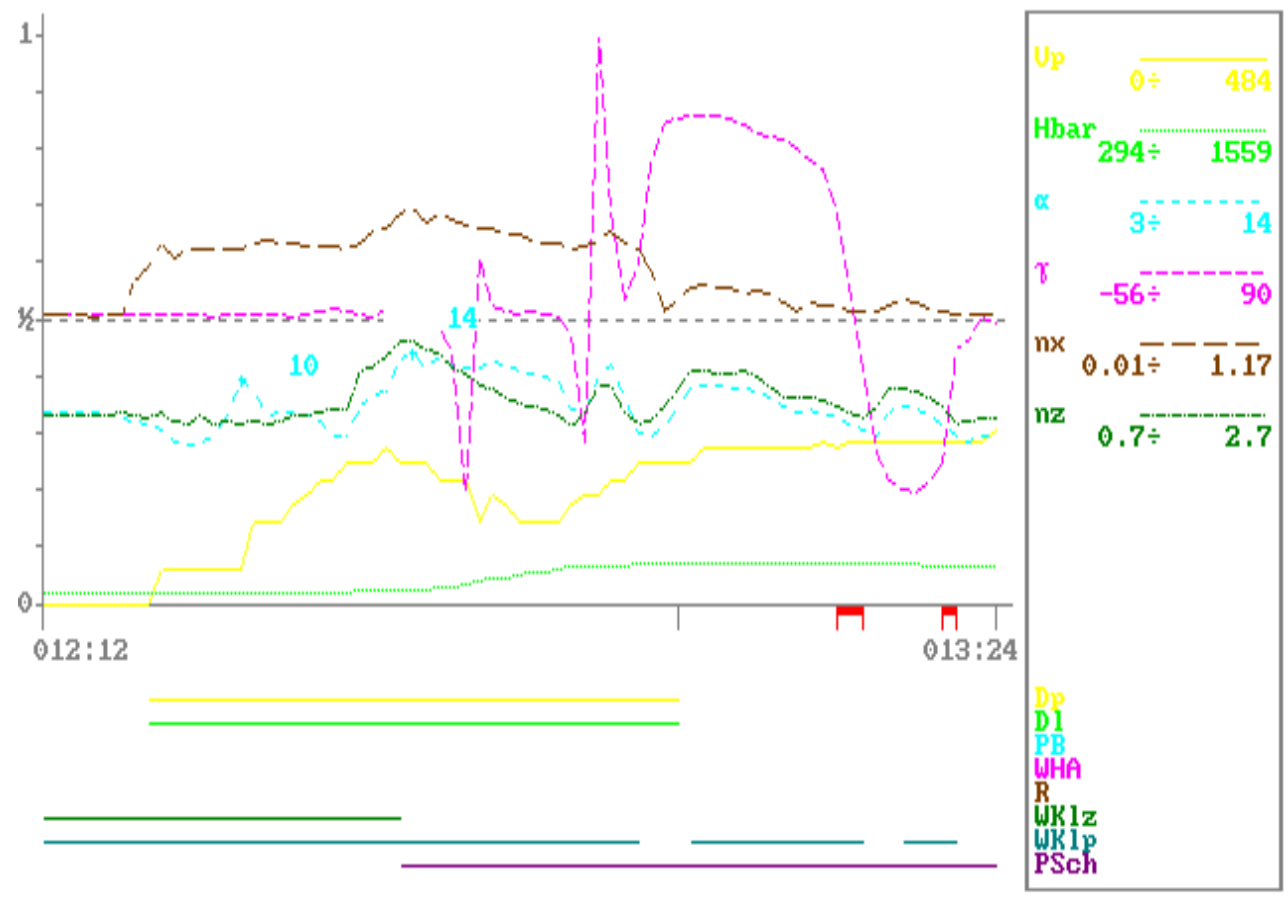

MiG-29U 4615 WYLOT:3 CWICZENIE:0019

Fig. 2. Start at the afterburning performed by the pilot No. 1 


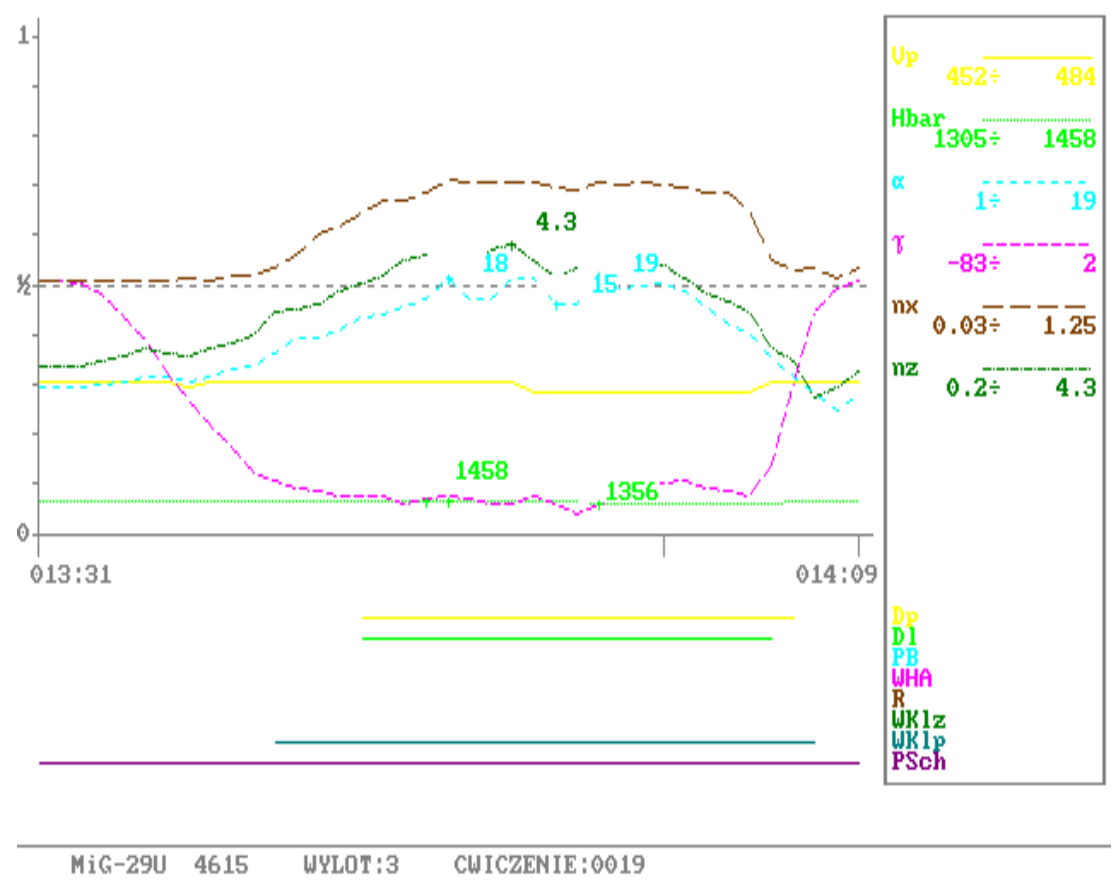

Fig. 3. Climbing turn at the afterburning performed by the pilot No. 1

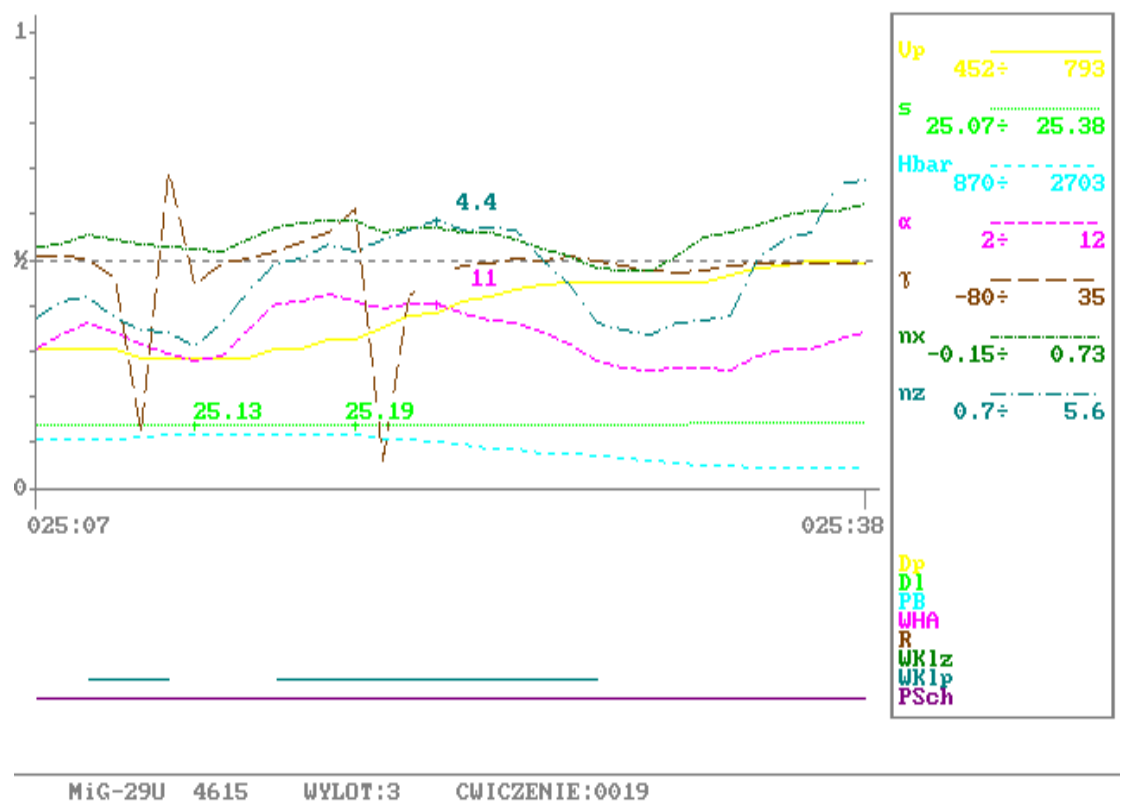

Fig. 4. Stall turn performed by the pilot No. 1 
Management of the training process of military pilots ...

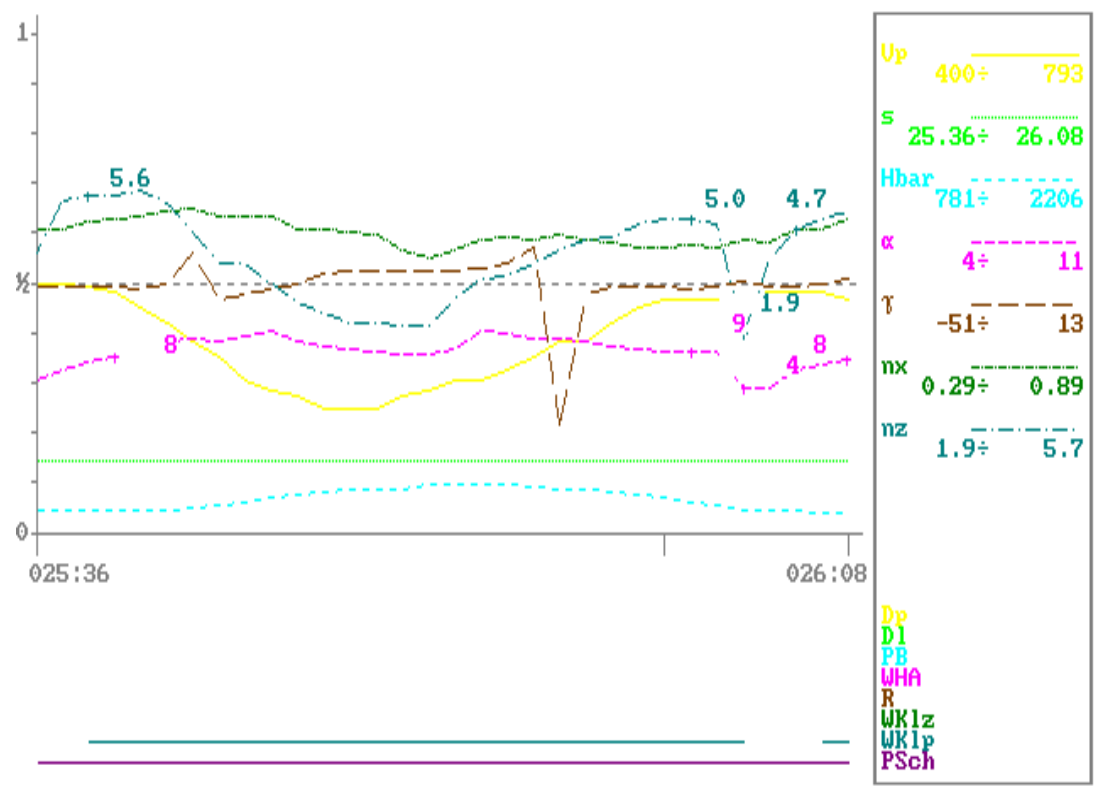

MiG-29U 4615 WYLOT:3 CWICZENIE:0019

Fig. 5. Loop performed by the pilot No. 1

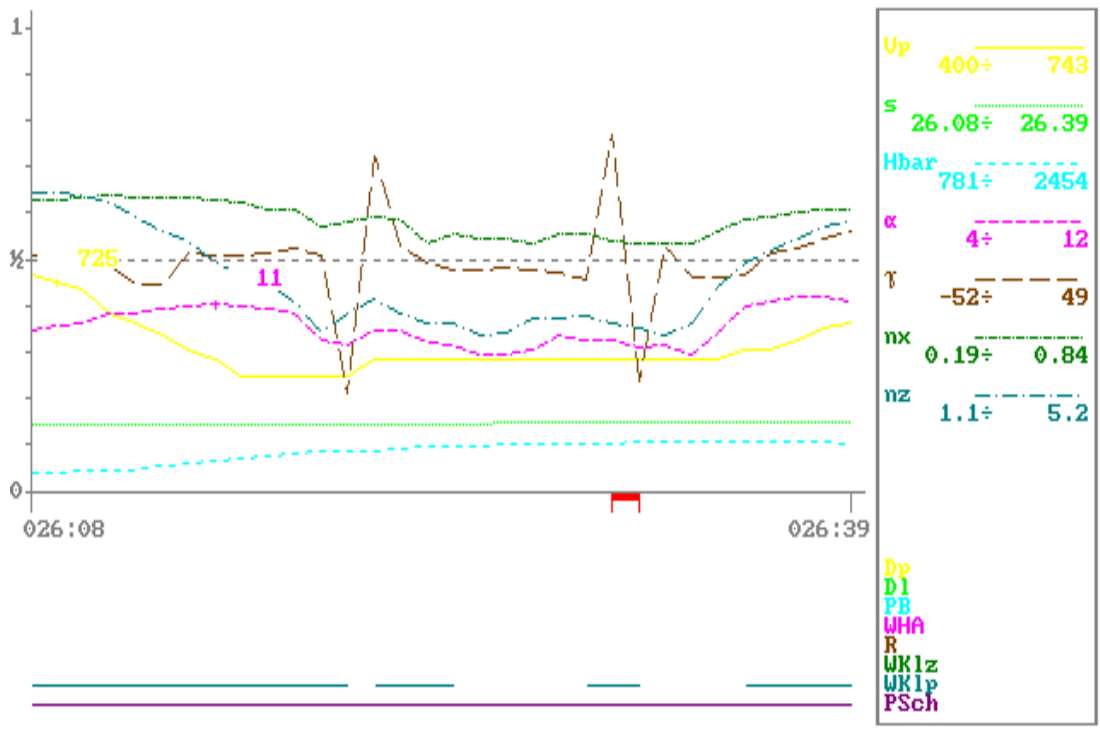

MiG-29U 4615 WYLOT:3

Fig. 6. Immelman performed by the pilot No. 1 


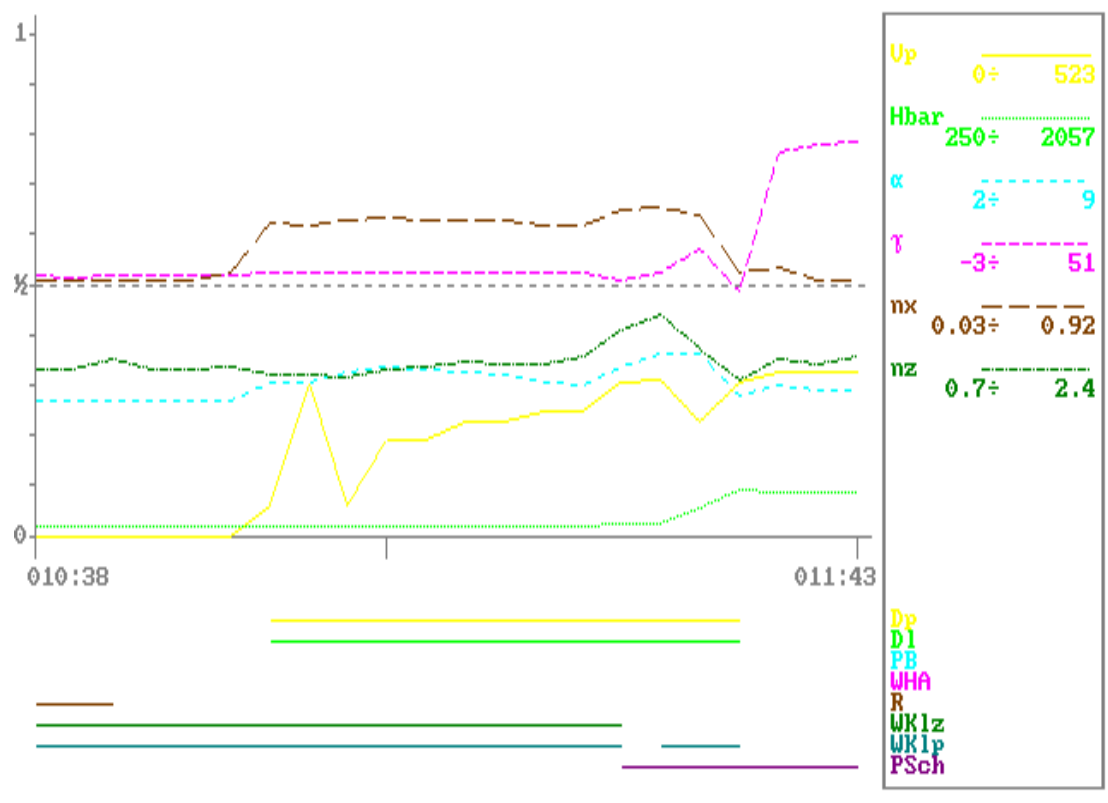

\section{MiG-29U 4615 WYLOT:2 CWICZENIE:0019}

Fig. 7. Start at the afterburning performed by the pilot No. 2

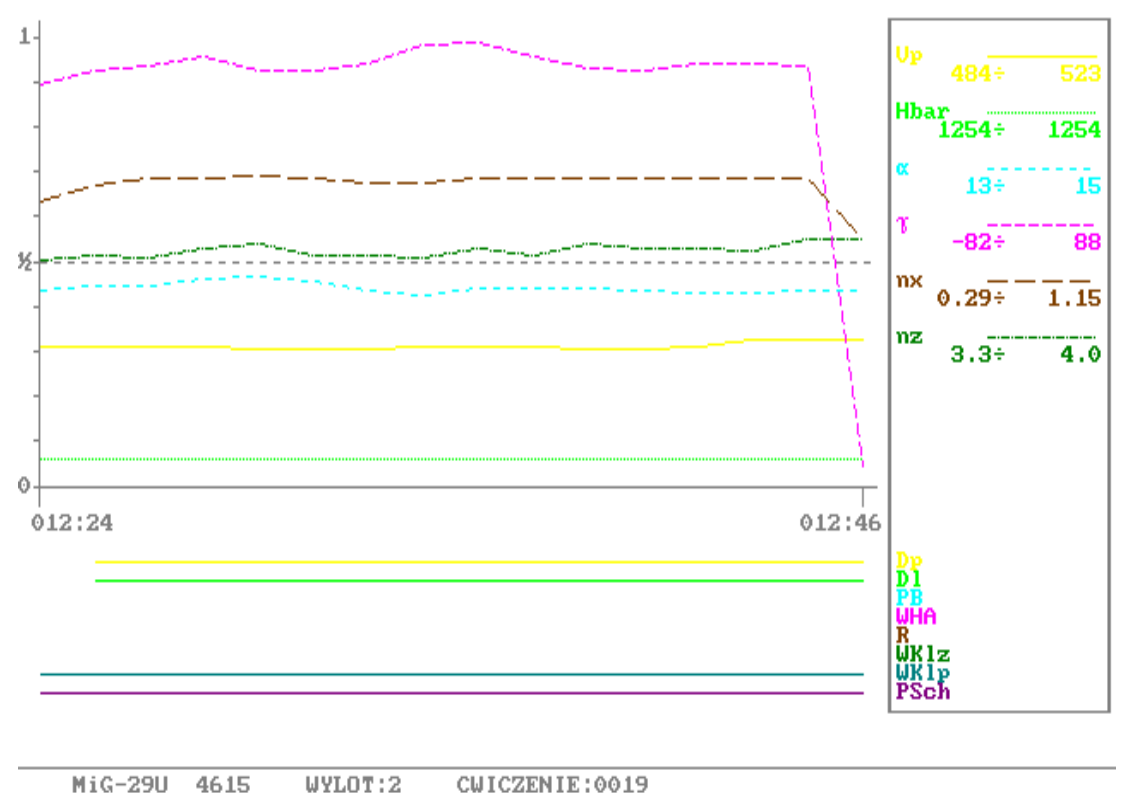

Fig. 8. Climbing turn at the afterburning performed by the pilot No. 2 
Management of the training process of military pilots ...

Zarzadzanie procesem szkolenia pilotów wojskowych...

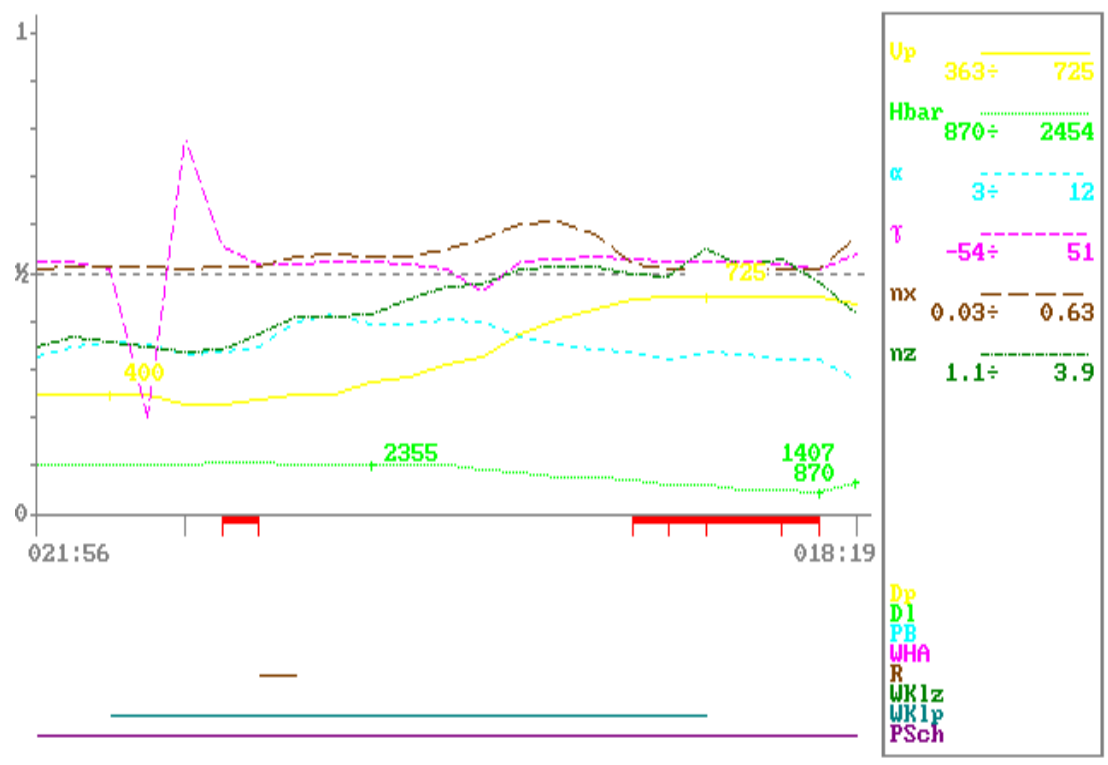

MiG-29U 4615 WYLOT:2 $\quad$ CWICZENIE:0019

Fig. 9. Stall turn performed by the pilot No. 2

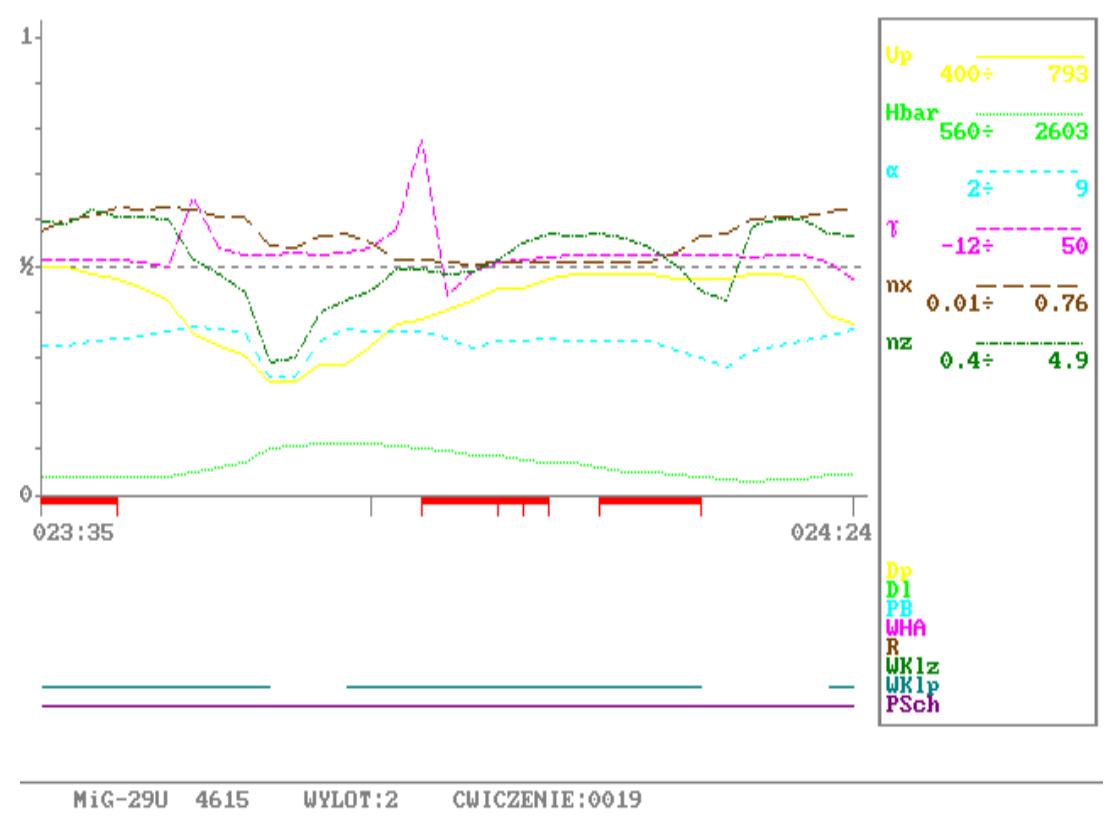

Fig. 10. Loop performed by the pilot No. 2 


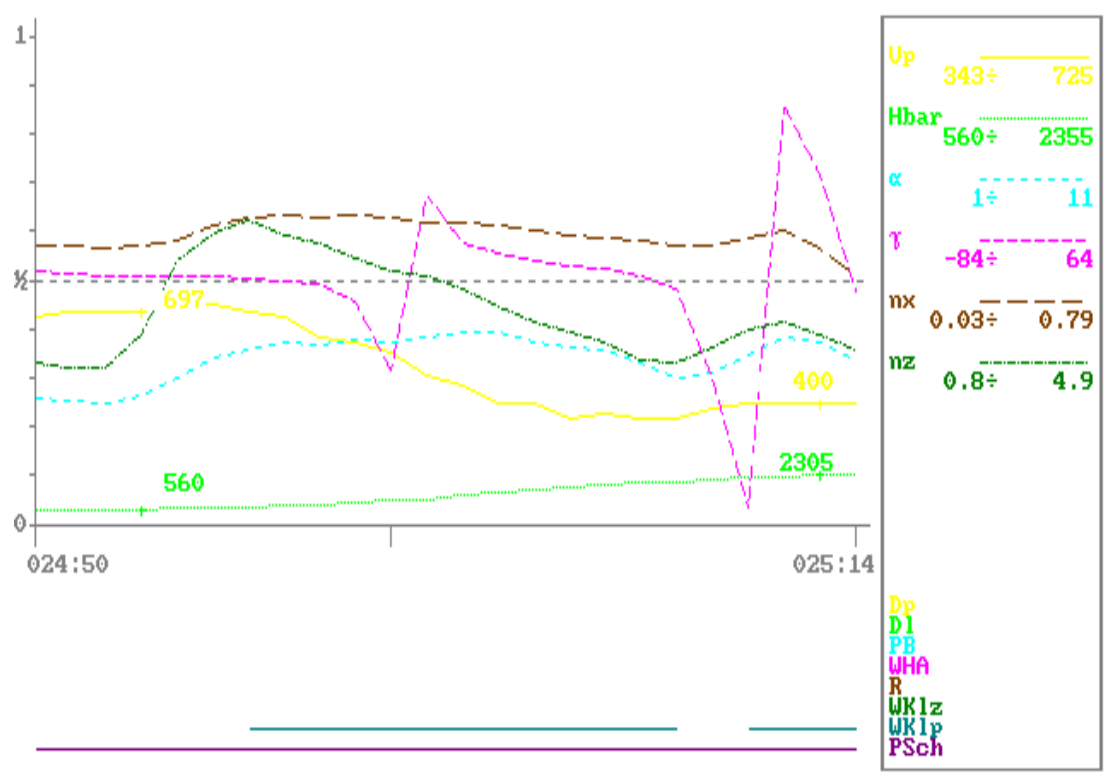

MiG-29U 4615 WYLOT:1 CWICZENIE:0019

Fig. 11. Immelman performed by the pilot No. 2

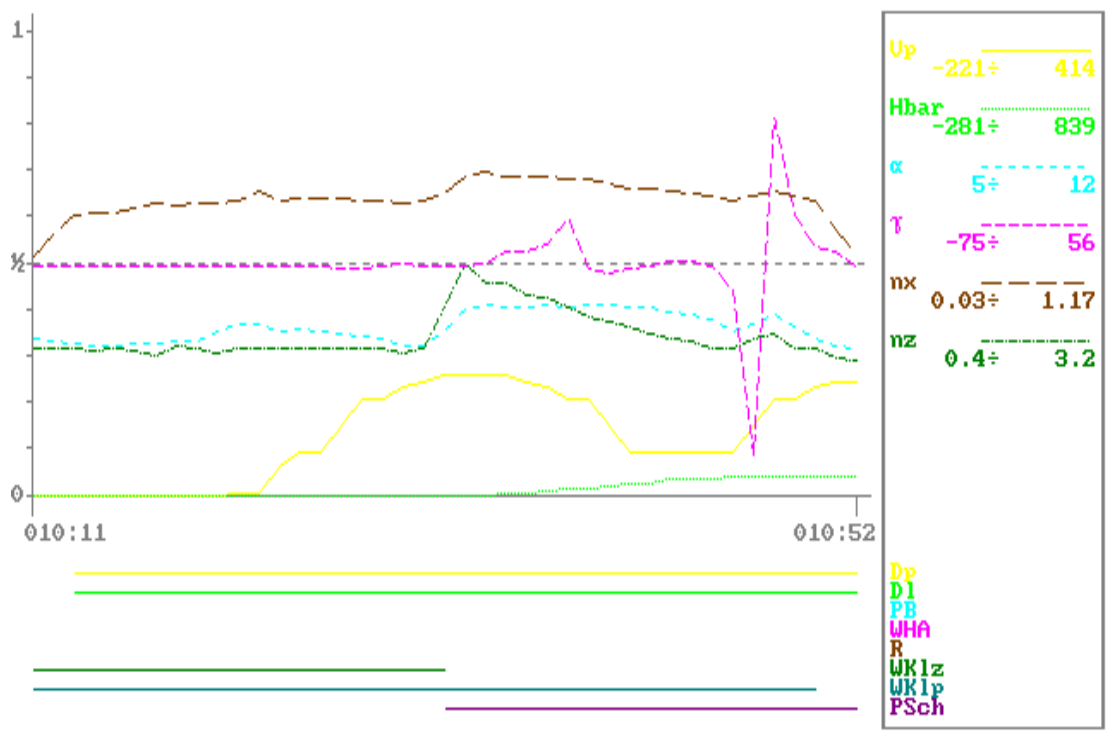

$\begin{array}{llll}\text { MiG-29U } & 4628 & \text { WYLOT:2 } & \text { CWICZENIE :0019 }\end{array}$

Fig. 12. Start at the afterburning performed by the pilot No. 3 
Management of the training process of military pilots ...

Zarzadzanie procesem szkolenia pilotów wojskowych...

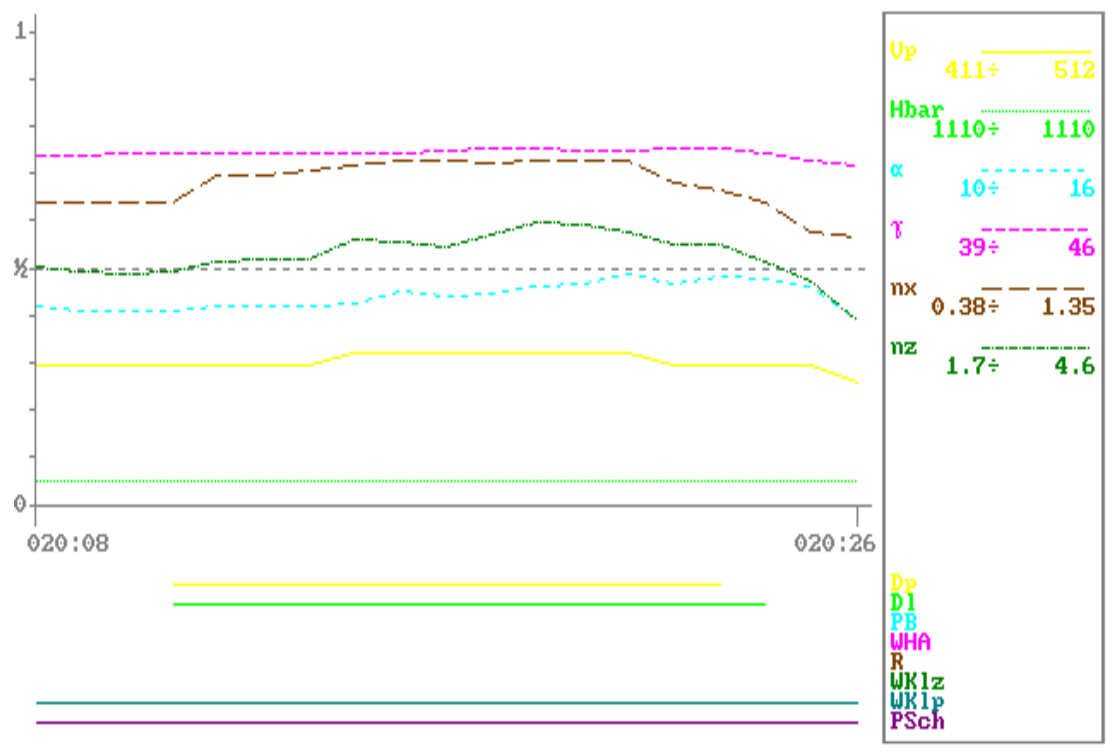

$\begin{array}{llll}\text { MiG-29U } 4642 & \text { WYLOT:5 } & \text { CWICZENIE:0019 }\end{array}$

Fig. 13. Climbing turn at the afterburning performed by the pilot No. 3

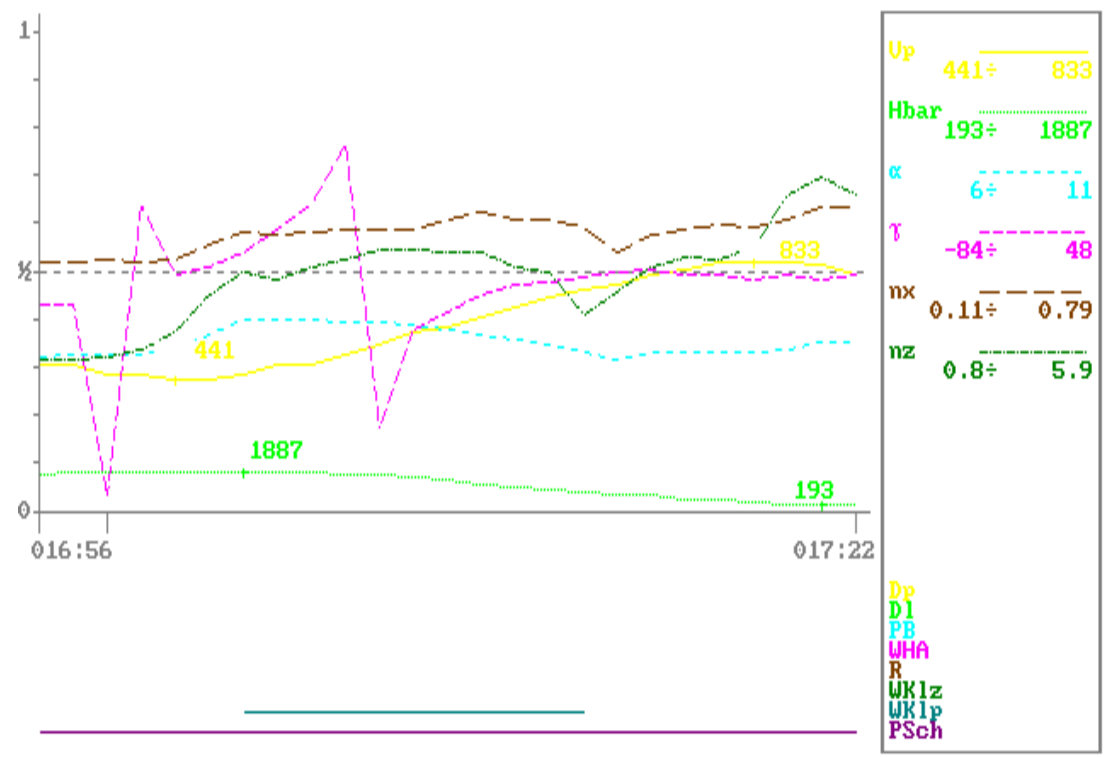

MiG-29U 4628 WYLOT:2 CWICZENIE:0019

Fig. 14. Stall turn performed by the pilot No. 3 
Mariusz Zieja, Henryk Smoliński, Pawet Gotda

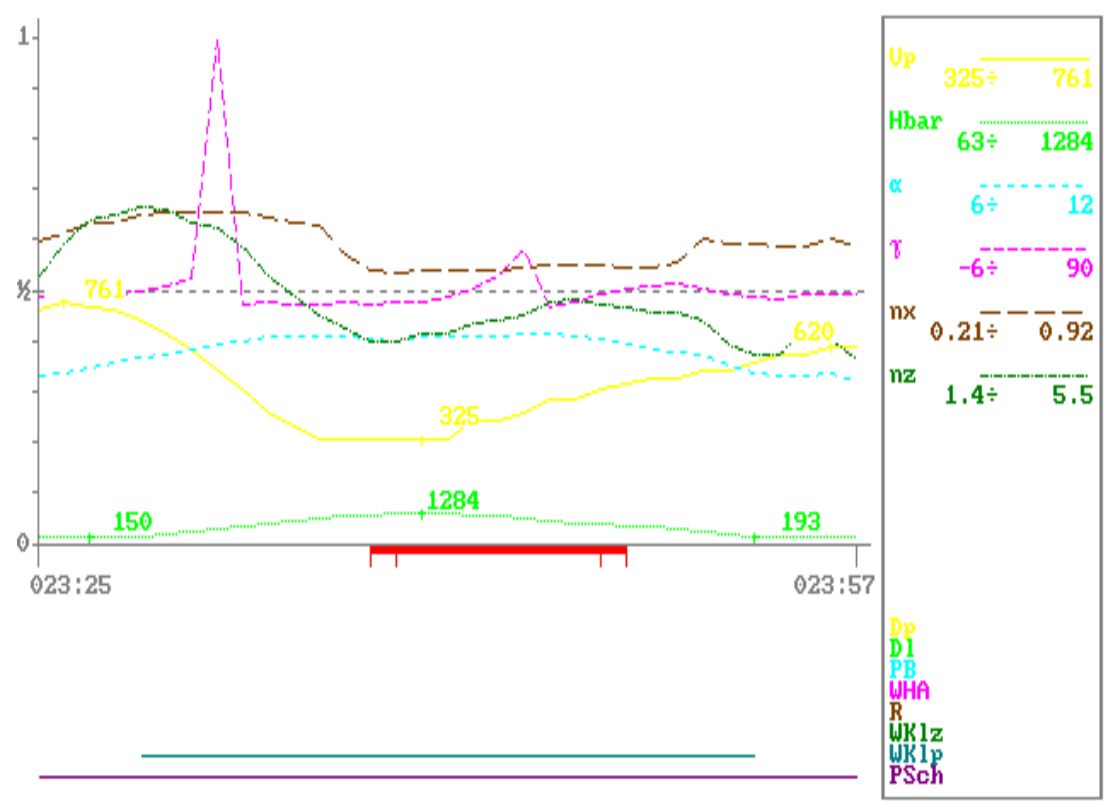

$\begin{array}{llll}\text { MiG-29U } & 4628 & \text { WYLOT:2 } & \text { CWICZENIE:0019 }\end{array}$

Fig. 15. Loop performed by the pilot No. 3

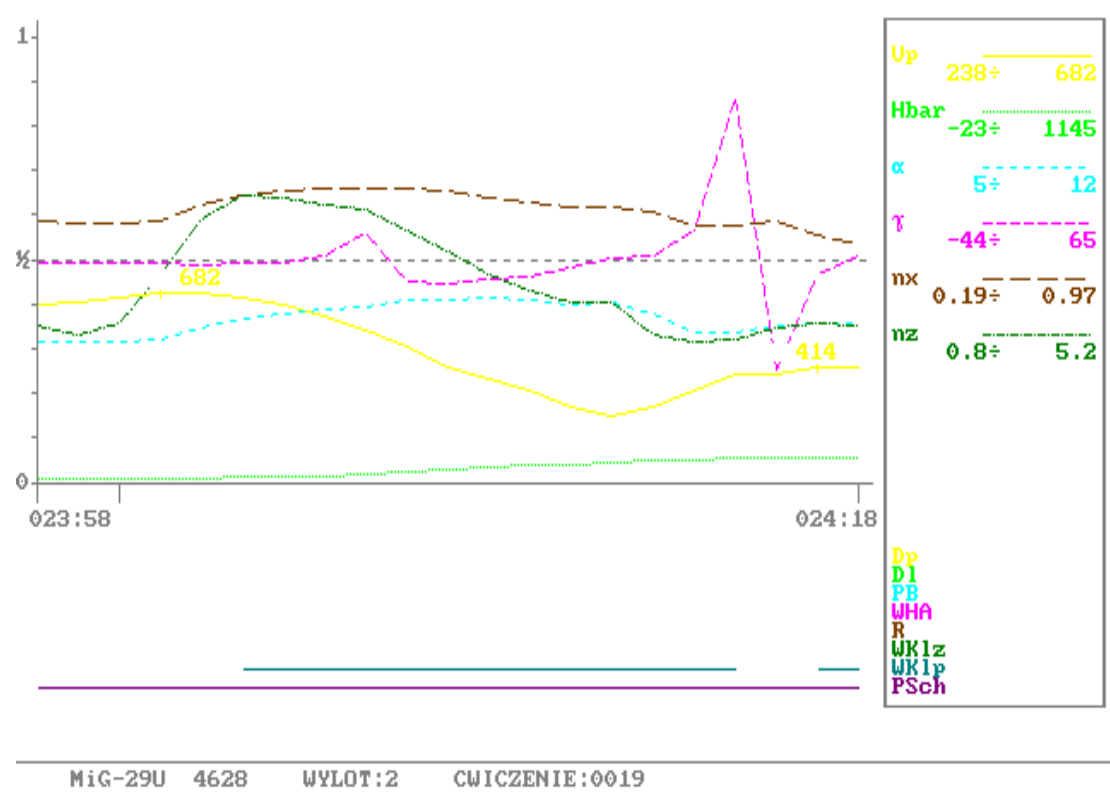

Fig. 16. Immelman performed by the pilot No. 3 
Management of the training process of military pilots ...

Zarzadzanie procesem szkolenia pilotów wojskowych...

Table 1 Markings of parameters for the Aviation Training Centre materials subjected to the comparative analysis

\begin{tabular}{|c|c|c|c|}
\hline Parameter & Record type & Colour & $\begin{array}{c}\text { Range } \\
\text { (on the basis of THETYS IV } \\
\text { programme for Mig - 29) }\end{array}$ \\
\hline $\mathbf{V p}$ & Analogue & Yellow & $0-2450 \mathrm{~km} / \mathrm{h}$ \\
\hline Hbar & Analogue & Green & $0-22000 \mathrm{~m}$ \\
\hline Alfa & Analogue & Blue & $-2-22^{0}$ \\
\hline Gamma & Analogue & Pink & $-90-90^{0}$ \\
\hline $\mathbf{N x}$ & Analogue & Brown & $-3-3 g$ \\
\hline $\mathbf{N z}$ & Analogue & Dark green & $-3.5-10 \mathrm{~g}$ \\
\hline Dp & Binary & Yellow & Left engine afterburner \\
\hline DL & Binary & Green & Right engine afterburner \\
\hline PB & Binary & Blue & Combat button \\
\hline WHA & Binary & Pink & Released air brake \\
\hline WKLz & Binary & Brown & Swung wing flaps \\
\hline WKLp & Binary & Dark green & Swung front flaps \\
\hline PSch & Binary & Purple & Stowed landing gear \\
\hline
\end{tabular}

The results of the carried out analysis of Mig-29 aircraft piloting figures on the basis of the Aviation Training Centre materials were presented in Table 2. 
Mariusz Zieja, Henryk Smoliński, Pawet Gołda

Table 2 Comparative analysis of Mig-29 aircraft piloting figures on the basis of the Aviation Training Centre materials

\begin{tabular}{|c|c|c|c|c|}
\hline Item & $\begin{array}{c}\text { Manoeuvre } \\
\text { type }\end{array}$ & Pilot No. 1/Remarks & Pilot No. 2/Remarks & $\begin{array}{l}\text { Pilot No. } \\
\text { 3/Remarks }\end{array}$ \\
\hline 1 & $\begin{array}{l}\text { Start at the } \\
\text { afterburning / } \\
\text { performance } \\
\text { of Immelman } \\
\text { turn }\end{array}$ & $\begin{array}{l}\text { The aircraft raising at } \alpha-10^{\circ} \text { and } \\
\text { then climbing to the altitude of } \\
200 \mathrm{~m} \text { (climb speed and } 1-2 \mathrm{~m} / \mathrm{s}) \\
\text { and the beginning of the } \\
\text { performance of Immelman } \\
\text { figure-(Fig. 2). }\end{array}$ & $\begin{array}{l}\text { The aircraft raising and } \\
\text { acceleration in the hori- } \\
\text { zontal flight to Vp of } \\
\text { approx. } 450 \mathrm{~km} / \mathrm{h} \text {, then the } \\
\text { beginning of the perfor- } \\
\text { mance of Immelman } \\
\text { figure. The figure does not } \\
\text { end with a smooth half } \\
\text { barrel-roll (Fig. 7). }\end{array}$ & $\begin{array}{l}\text { Properly } \\
\text { performed - } \\
\text { (Fig. 12). }\end{array}$ \\
\hline 2 & $\begin{array}{l}\text { Climbing } \\
\text { turn at the } \\
\text { afterburning }\end{array}$ & $\begin{array}{l}\text { The climbing turn was not } \\
\text { performed in a fluent manner - } \\
\text { with } n_{z} \text { variable overload and } \alpha \\
\text { as well as with the loss of height } \\
\text { - (Fig. 3). }\end{array}$ & $\begin{array}{l}\text { The climbing turn } \\
\text { performed in a fluent } \\
\text { manner }-(\text { Fig. } 8) \text {. }\end{array}$ & $\begin{array}{l}\text { Properly } \\
\text { performed - } \\
\text { (Fig. 13). }\end{array}$ \\
\hline 3 & Stall turn & $\begin{array}{l}\text { Between the aircraft turn by } 180^{\circ} \\
\text { (half barrel-roll) and a further } \\
\text { phase of the figure, there is a } \\
\text { time gap of } 5 \text { seconds. The time } \\
\text { gap results in a decrease of the } \\
\text { introduction altitude - (Fig. } 4 \text { ) }\end{array}$ & $\begin{array}{l}\text { After moving the aircraft } \\
\text { from the stall turn, the } \\
\text { pilot does not allow for } \\
\text { the horizontal flight - } \\
\text { (Fig. 9). }\end{array}$ & $\begin{array}{l}\text { Properly } \\
\text { performed - } \\
\text { (Fig. 14). }\end{array}$ \\
\hline 4 & Loop & $\begin{array}{l}\text { The vertical loop performed too } \\
\text { tight. In the final stage of the } \\
\text { figure, there is the stick } \\
\text { instantaneous handing in order } \\
\text { to achieve the imposed height of } \\
\text { the end of the loop. It results in } \\
\text { the flight short-term } \\
\text { destabilisation and decrease in } \mathrm{n}_{\mathrm{z}} \\
\text { load and } \alpha-\text { (Fig. 5) }\end{array}$ & $\begin{array}{l}\text { The first part of the loop } \\
\text { (climbing) performed in } \\
\text { a tighter manner than the } \\
\text { other. After ending the } \\
\text { loop, the pilot does not } \\
\text { allow for the horizontal } \\
\text { flight-(Fig. 10). }\end{array}$ & $\begin{array}{l}\text { Properly } \\
\text { performed - } \\
\text { (Fig. 15). }\end{array}$ \\
\hline 5 & Immelman & $\begin{array}{l}\text { Introduction to Immelman from } \\
\mathrm{Vp}=700 \text {. Properly performed } \\
\text { Immelman - (Fig. } 6)\end{array}$ & $\begin{array}{l}\text { Properly performed } \\
\text { Immelamn - (Fig. 11). }\end{array}$ & \begin{tabular}{|c|} 
Properly \\
performed - \\
(Fig. 16). \\
\end{tabular} \\
\hline \multirow{2}{*}{6} & \multirow{2}{*}{ Remarks } & $\begin{array}{l}\text { The presented exercise was } \\
\text { performed by the pilot three } \\
\text { more times with different } \\
\text { instructors with the use of the } \\
\text { above elements, both with the use } \\
\text { of afterburning and without it. }\end{array}$ & $\begin{array}{l}\text { In the next flight, all the } \\
\text { presented figures were } \\
\text { properly performed by } \\
\text { the pilot, both in the } \\
\text { field of afterburning and } \\
\text { in the range of } \\
\text { maximum engine speed. }\end{array}$ & \\
\hline & & $\begin{array}{l}\text { On the basis of the analysis of } \\
\text { the Aviation Training Centre } \\
\text { materials, it is possible to } \\
\text { unambiguously state that all the } \\
\text { figures or manoeuvres with the } \\
\text { use of afterburning caused some } \\
\text { difficulties to the pilot. }\end{array}$ & $\begin{array}{l}\text { In subsequent flights, the } \\
\text { pilot performed all the } \\
\text { figures in a correct } \\
\text { manner. }\end{array}$ & \\
\hline
\end{tabular}


Management of the training process of military pilots ...

Zarzadzanie procesem szkolenia pilotów wojskowych...

\section{Analysis of the aircraft flight during the performance of piloting figures with the use of a graphic model}

\section{Calculation of the aircraft trajectory}

If the on-board recorder allows to record speed by the instrument and aircraft angular position in order to calculate the flight trajectory, the following activities are performed [1]:

1) The actual flight speed in the speed coordinate system is determined. As the recording system record the speed by the instruments in the speed coordinate system, it is important to adjust the speed in accordance with the instrument with the use of adjustments to obtain the indicator speed

$$
V_{i}=V_{p r z}+\delta V_{a}+\delta V_{i n s t r}+\delta V_{s t},
$$

Where:

$\mathrm{V}_{\mathrm{prz}}$ - speed by instruments, recorded by on-board measures;

$\delta V_{a}$ - aerodynamic adjustment (including the sensor's indications while changing flight conditions);

$\delta V_{\text {inst }}$ - instrumental adjustment (including construction properties and technological shortcomings of the sensor construction);

$\delta V_{s t}$ - adjustment to the environment stability.

The mentioned adjustments can be found in the Aeroplane Flight Manual for a given type of aircraft. As a rule, they are functionally dependent on the flight altitude and speed and the aircraft wing configuration;

2) The actual speed according to the indicator speed is calculated

$$
V_{i c}=V_{i} / \sqrt{\Delta}
$$

Where:

$\Delta$ - the ratio of the air density at the flight altitude to the density at the sea level $\left(\Delta=\rho_{H} / \rho_{0}\right)$. Proper values of the air density $\rho_{0}, \rho_{H}$ are calculated in accordance with the international standard atmosphere;

3) Speed on the axes of the related coordinate system is calculated.

$$
\begin{aligned}
& V_{x}=V_{i c} \cos \alpha \cos \beta, \\
& V_{y}=-V_{i c} \sin \alpha \cos \beta ; \\
& V_{z}=V_{i c} \sin \beta ;
\end{aligned}
$$

4) With the angles, which characterise the aircraft position in the space $(\vartheta, \gamma, \psi)$, speed projections in the normal coordinate system (excluding wind speed) are calculated. 
$V_{x g}^{\prime}=V_{x} \cos \vartheta \cos \psi-V_{y}(\sin \vartheta \cos \gamma \cos \psi-\sin \gamma \sin \psi)+V_{z}(\sin \vartheta \sin \gamma \cos \psi+\cos \gamma \sin \psi) ;$

$V_{y g}^{\prime}=V_{x} \sin \vartheta+V_{y} \cos \vartheta \cos \gamma-V_{z} \cos \vartheta \sin \gamma ;$

$$
V_{z g}^{\prime}=-V_{x} \cos \vartheta \sin \psi+V_{y}(\cos \gamma \cos \psi-\sin \vartheta \sin \gamma \sin \psi)
$$

5) The obtained data on wind speed in accordance with the flight trajectory is adjusted.

$$
\begin{aligned}
& V_{x g}=V_{x g}^{\prime}+W_{x g} ; \\
& V_{y g}=V_{y g}^{\prime}+W_{y g} ; \\
& V_{z g}=V_{z g}^{\prime}+W_{z g}
\end{aligned}
$$

6) Integration of equations with obtained speed projections allows to achieve the flight trajectory projections on appropriate planes.

In this coordinate system, the flight trajectory is characterised by projections on correct planes (surfaces): vertical $O X_{g} Y_{g}$; horizontal $O X_{g} Z_{g}$; side $O Y_{g} Z_{g}$. Projections of the aircraft position on appropriate axes of this coordinate system are calculated from the relationships:

$$
\left.\begin{array}{l}
X_{g}=\int_{t_{1}}^{t_{2}} V_{x g}+X_{g 0} \\
Y_{g}=\int_{t_{1}}^{t_{2}} V_{y g}+Y_{g 0} \\
Z_{g}=\int_{t_{1}}^{t_{2}} V_{g}+Z_{g 0}
\end{array}\right\}
$$

Where:

$t_{1}$ - time value from the beginning of which the trajectory is prepared;

$\mathrm{t}_{2}$ - final time value;

$X_{g 0}, Y_{g 0}, Z_{g 0}-$ initial values of the aircraft position parameters in the time $\mathrm{t}_{1}$;

$V_{x g}, V_{y g}, V_{z g}$ - speed projections of the aircraft mass centre on axes of the normal coordinate system $O X_{g} Y_{g} Z_{g}$.

Depending on the collection of parameters of the aircraft movement that is recorded, calculation variants of speed $V_{x g}, V_{y g}, V_{z g}$. are possible.

\section{Example of the aircraft trajectory analysis}

As an example of the manoeuvring aircraft trajectory analysis during the performance of advanced flight manoeuvres, a training flight [1] was selected, and it included the following figures: "Barrel-roll", "loop sequence", with the stall turn; "loop"; "loop with the stall turn"; "climbing turn"; "tail slide", "inverted flight" barrel-roll - inverted flight, stall turn to $270^{\circ}$. 
Management of the training process of military pilots ...

Zarzadzanie procesem szkolenia pilotów wojskowych...

In the on-board system, the following elements were recorded:

- speed by instruments - $\mathrm{V}_{\mathrm{prz}}$,

- flight altitude (radar altimeter) - $\mathrm{H}$;

- local angle of attack - $\alpha_{m}$;

- angle of bank - $\beta$;

- angle of tilt - $\gamma$;

- angle of lowering - $\vartheta$;

- angle of flight path - $\psi$;

The flight, which is the subject of assessing the quality related to the performance of piloting figures was implemented in accordance with the graphic model implementation and operational limitations presented in the Aeroplane Flight Manual for a given type of aircraft. The comparative analysis of quality related to the performance of piloting figures based on recorded data from flight parameter on-board recorders, with the manual and graphic model requirements were presented in Table 3.

The flight graphic model - is a graph of the aircraft trajectory during the performance of separate figures with indicated characteristic points and values of the aircraft movement parameters in these points. The graphic model is developed according to a task given to the pilot, and it is a basic document for it.

In order to objectively assess the quality of the performed figures, the flight trajectory in accordance with the above presented relationships, was calculated. Fig. 17 shows the trajectory projection on a vertical plane.

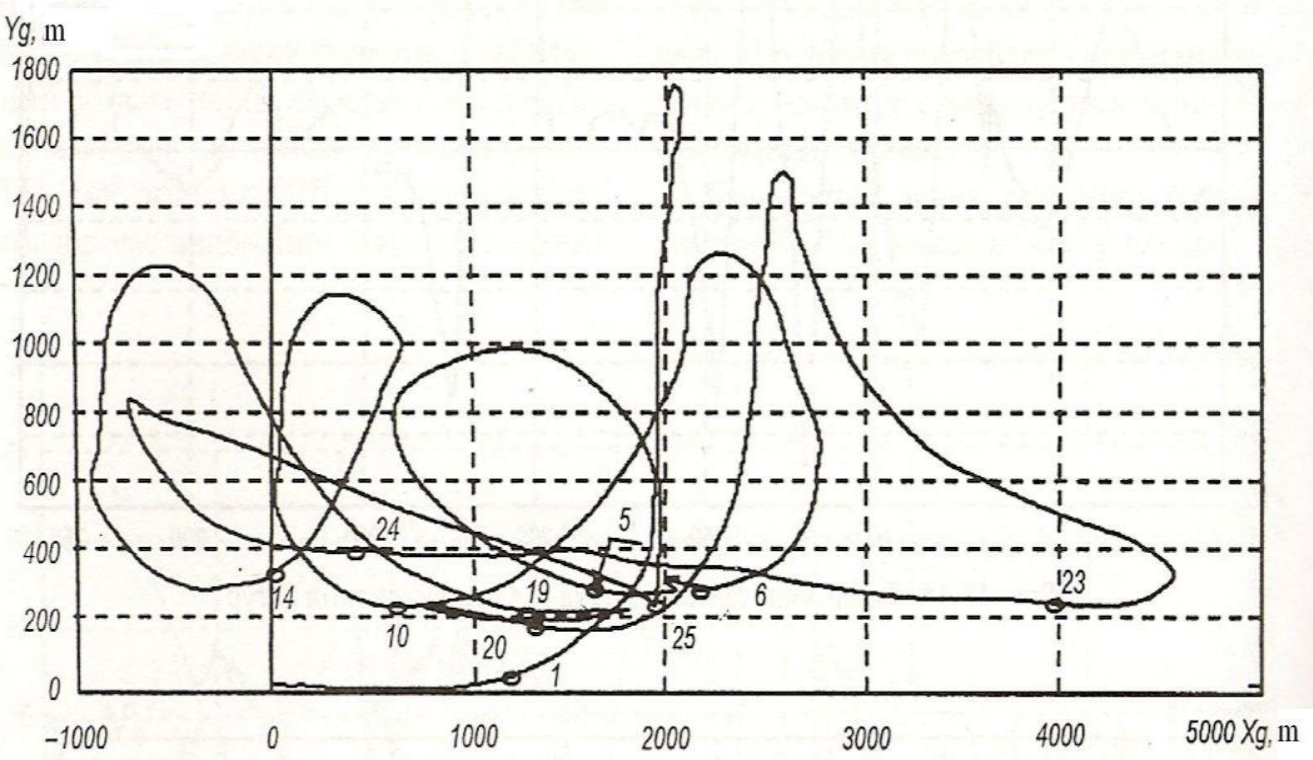

Fig. 17. Aircraft trajectory projection on a vertical plane [1] 
The aircraft trajectory projection on a horizontal plane was presented in Fig. 18.

The analysis of maximum altitude values of separate figures on a plane shows that they are consistent with the records of flight altitude values of these figures. The maximum absolute errors are in approx. $40 \mathrm{~m}$ in accordance with the altitude, which corresponds to the flight altitude record errors. It confirms that the trajectory was properly developed.

Fig. 18 also shows the points, thanks to which the figures are distinguished from each other. It is a conventional division because they are partly based on transitional sections of the aircraft movement, i.e. acceleration and braking sections.

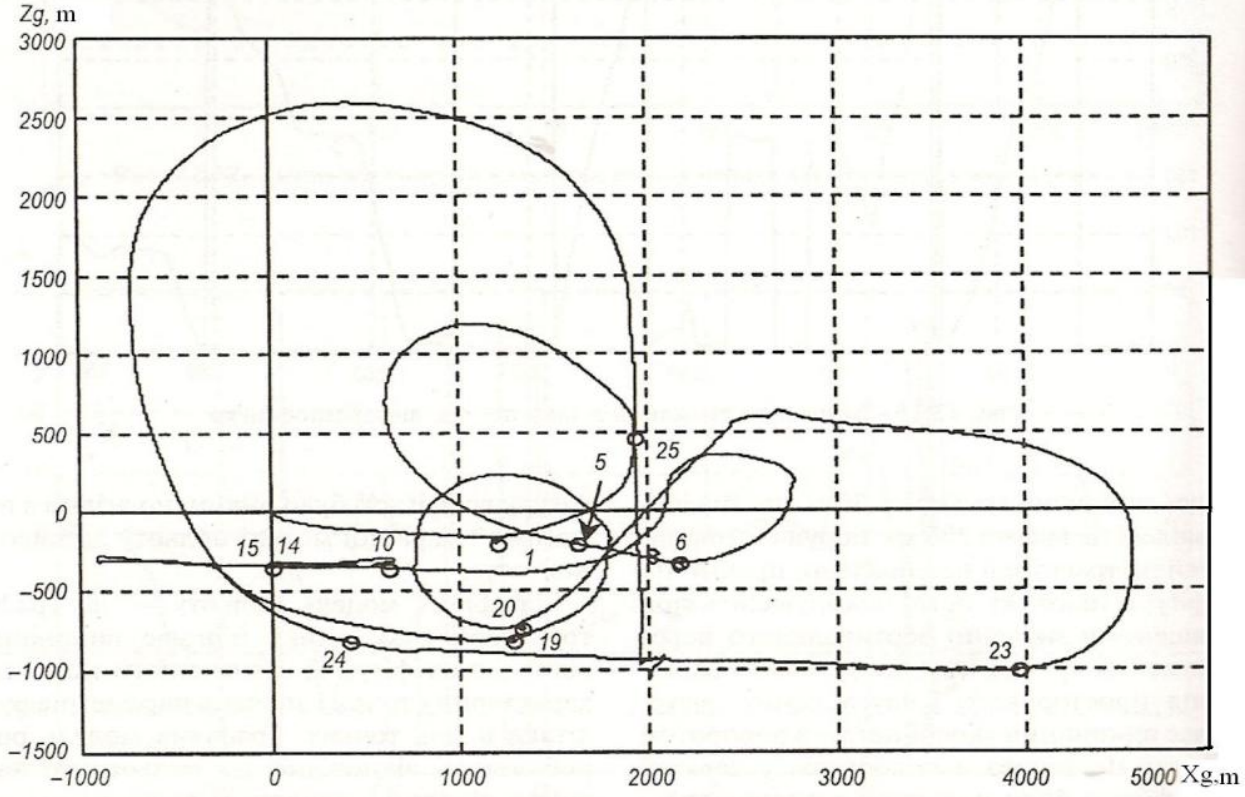

Fig. 18. Aircraft trajectory projection on a horizontal plane [1]

The following figures were determined:

1-5 - "Loop"- "barrel-roll"; 6-10- "loop with the stall turn"; 10-14- "loop"; 14-19"loop with the stall turn"; 19-20- "climbing turn"; 20-22- "tail slide"; 23-24"inverted flight - barrel-roll - inverted flight"; 24-25- turn by $270^{\circ}$.

The analysis of the above demonstrated graphs shows that in order to implement a set of nine presented figures, the trajectory projection on a vertical plane is consistent with a rectangle of $4500 \times 1500 \mathrm{~m}$.

The analysis of the aircraft flight trajectory projection on a horizontal plane shows that the aircraft flight trajectory projection on a horizontal plane is consistent with a rectangle of $4500 \mathrm{~m} \times 2500 \mathrm{~m}$. At the same time, among the listed figures on horizontal plane, the maximum area belongs to the figure with a turn of $270^{\circ}$ $2500 \mathrm{~m} \times 2600 \mathrm{~m}$. 
Management of the training process of military pilots ...

Zarzadzanie procesem szkolenia pilotów wojskowych...

The presented example shows that parameters recorded by the on-board system allow to analyse the aircraft piloting technique and detect substantial deviations, which affect the flight safety and make it possible to assess the quality of the air (flight) task implementation by the pilot. Table 3 contains an analysis of the flight performed by a single pilot. The procedure may be repeated for the entire group of trained pilots.

Table 3 Comparative analysis of quality of the performance of piloting figures on the basis of recorded data from the flight parameter on-board recorders

\begin{tabular}{|c|c|c|c|}
\hline Item & Figure type & $\begin{array}{l}\text { Limitations/ } \\
\text { requirements }\end{array}$ & Remarks \\
\hline 1. & Loop & \multirow{10}{*}{$\begin{array}{c}\text { Graphic model to the } \\
\text { task. } \\
\mathrm{Vp}<300 \mathrm{~km} / \mathrm{h} \text {, } \\
\mathrm{n}_{\mathrm{y}}<\text { in upper points } \\
\text { of figures in the } \\
\text { range of } 4.5 \ldots .5 .5 \text {. }\end{array}$} & $\begin{array}{l}\text { The access to the } \\
\text { performance of a figure } \\
\text { incompatible with the } \\
\text { graphic model. }\end{array}$ \\
\hline 2. & Barrel-roll & & $\mathrm{b} / \mathrm{u}$ \\
\hline 3. & $\begin{array}{l}\text { Loop with the stall } \\
\text { turn }\end{array}$ & & $\alpha>16^{\circ}$ \\
\hline 4. & Loop & & $\alpha>16^{\circ}$ \\
\hline 5. & $\begin{array}{l}\text { Loop with the stall } \\
\text { turn }\end{array}$ & & $\mathrm{b} / \mathrm{u}$ \\
\hline 6. & Climbing turn & & $\mathrm{b} / \mathrm{u}$ \\
\hline 7. & Tail slide & & $\begin{array}{l}\text { Developed for } \\
\text { demonstration flights. }\end{array}$ \\
\hline 8. & $\begin{array}{l}\text { Inverted flight - } \\
\text { barrel-roll - } \\
\text { inverted flight }\end{array}$ & & $\mathrm{b} / \mathrm{u}$ \\
\hline 9. & Turn by $270^{\circ}$ & & $\mathrm{b} / \mathrm{u}$ \\
\hline 10. & Flight in the zone & & $\begin{array}{l}\text { Flight was performed in the } \\
\text { zone, the sizes of which } \\
\text { were: } X=4500 \mathrm{~m} ; \mathrm{H}=1500 \\
\mathrm{~m} ; \mathrm{Z}=2600 \mathrm{~m} \text {.. }\end{array}$ \\
\hline
\end{tabular}

In order to carry out the above-mentioned analyses and assessment, the IT support is necessary as an important element of the aviation training process management. In Fig. 19, the structural graph of input - output data of the Flight Data Analysis of the military aviation was presented. 
In Fig. 20, an algorithm of the aircraft flight analysis based on the record of its parameters by the on-board record system, which includes three stages with a proposal of using TURAWA IT system functioning in the military aviation, was presented:

- collection of data on aircraft, carried out task, aircraft crew and others;

- analysis of the flight information record;

- evaluation of information, preparation of documentation and its archiving.

The collection of data and information in the system will be used for a further analysis, as a result of which the problems, to be solved in the aviation training process, should be identified.

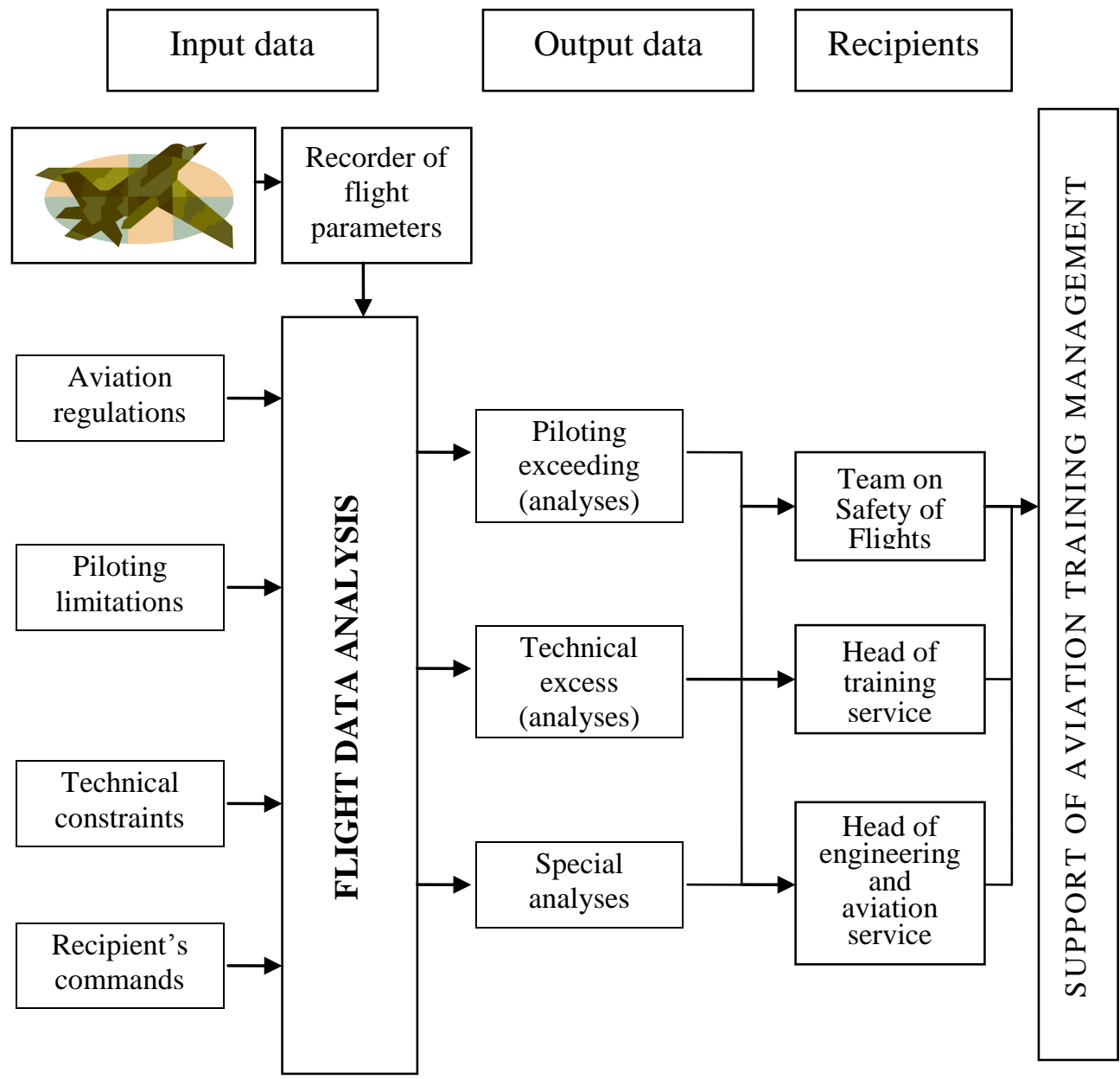

Fig. 19. Structural graph of input - output data of the Flight Data Analysis of military aviation 


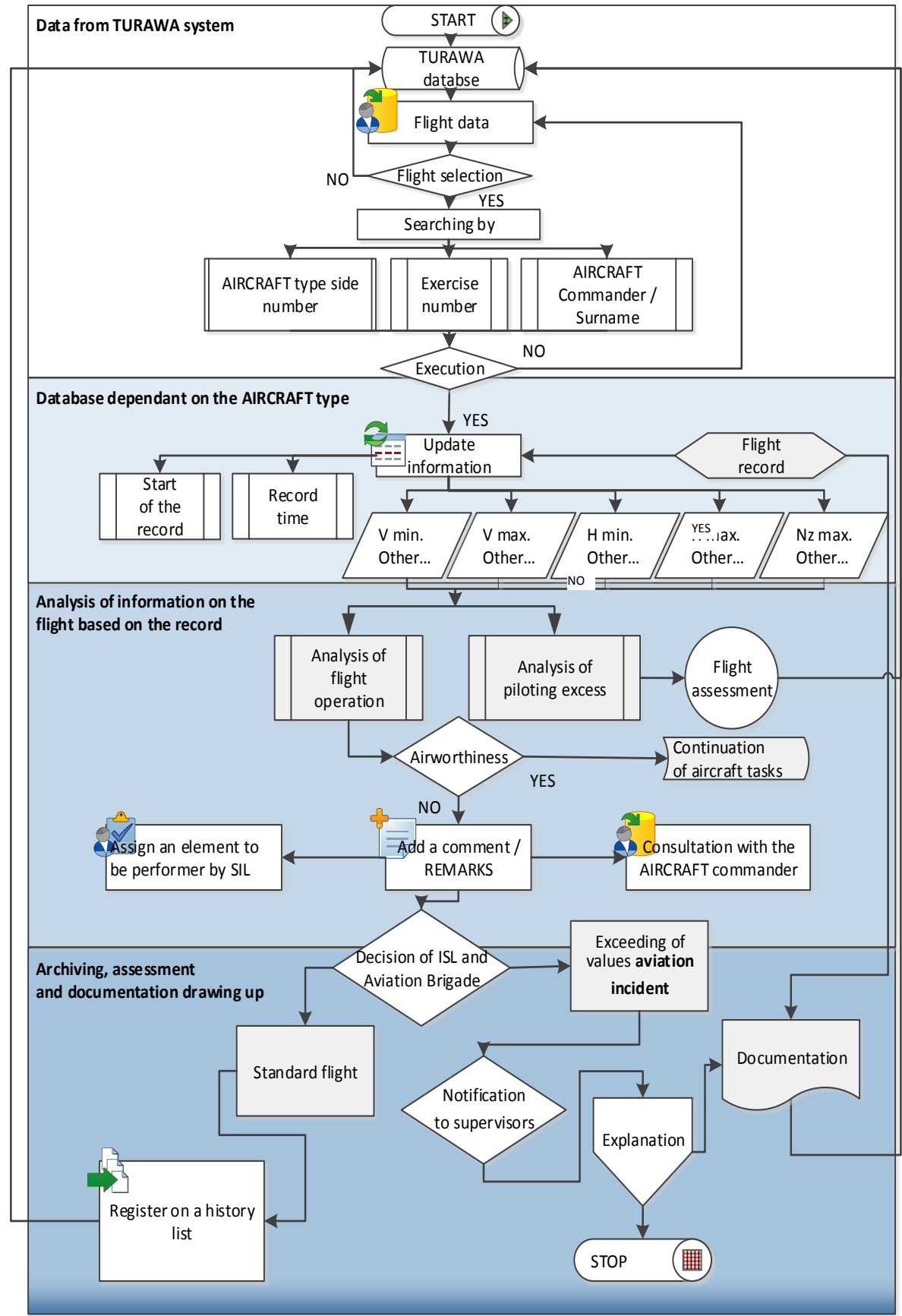

Fig. 20 Algorithm of the aircraft flight analysis with the use of TURAWA IT system 


\section{Algorithm of supporting the training process of pilots of military aircraft}

The methodology of supporting the training process of pilots of military aircraft can be formulated as an algorithm (Fig. 21). The algorithm was based on the determination of training susceptibility of the "aircraft-pilot" system on the basis of subjective assessment related to correctness of the performance of piloting figures carried out by the pilot-instructor, which is subject to verification based on records of flight parameters in the materials from the objective flight control.

The algorithm begins with picking of a training group and choosing the aircraft intended for training pilots. Then, the assessment of characteristics of pilots selected to carry out the scheduled training is conducted. In parallel, the assessment of characteristics of the aircraft intended for training is carried out.

The next stage of the proposed algorithm is to determine a set of necessary exercises provided by the training programme in order to achieve required skills by trained pilots.

During the training process implementation, correctness of performing individual piloting figures is assessed by the pilot-instructor. The subjective assessment of correctness related to the performance of piloting figures conducted by the pilotinstructor is subject to verification based on recorded parameters in the system of objective control of flights.

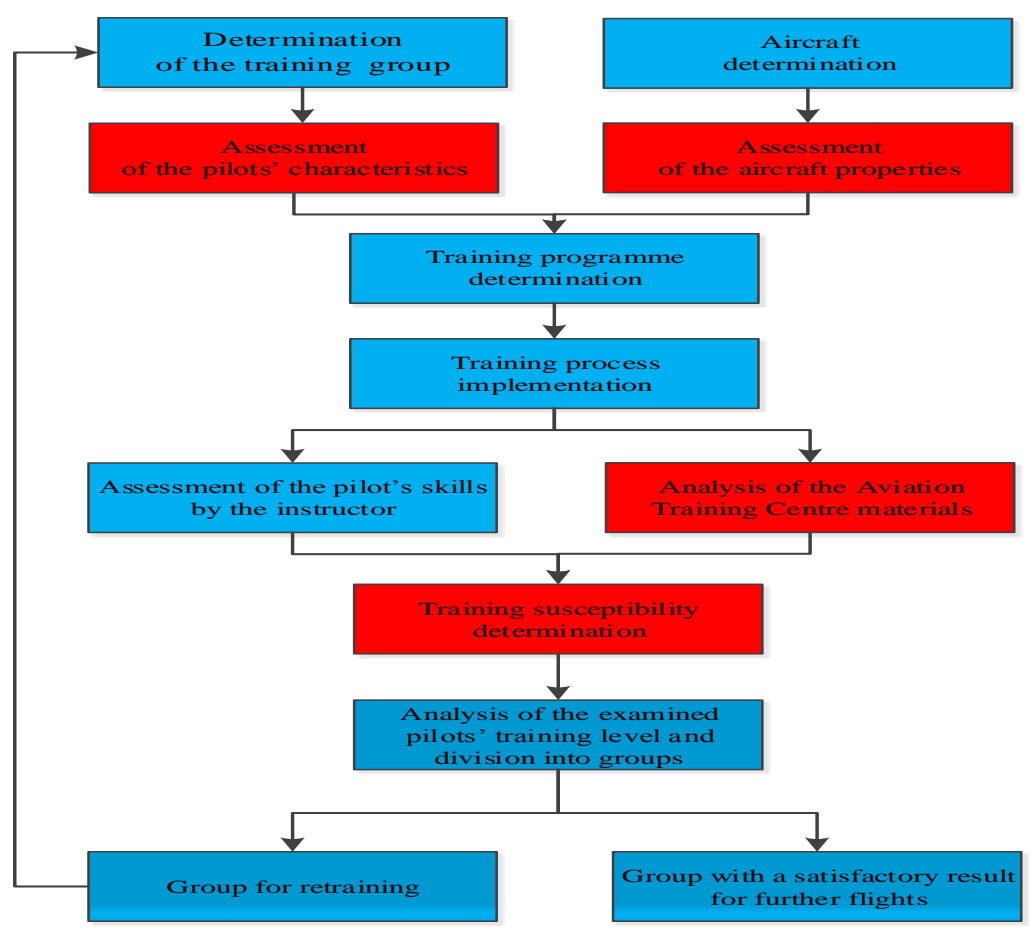

Fig. 21. Algorithm of supporting the training process of pilots of military aircraft [2] 
Management of the training process of military pilots ...

Zarzadzanie procesem szkolenia pilotów wojskowych...

After determination of the training susceptibility with regard to interruptions in the continuity of the performance of subsequent stages of training, individual modification of the training programme is carried out for each pilot.

After completion of the training process, a training level of examined pilots is analysed. On the basis of the obtained results, the pilots are re-qualified to relevant training groups.

\section{Conclusion}

The parametric information records accumulated with the use of on-board flight data recording media constitute an extremely important source of information to the aircraft flight analysis. The recorded parameters make it possible to analyse the safety status of flights during the performance of piloting figures by a pilot. The warranty of a determined safety level of flights includes operational limitations presented in the Aeroplane Flight Manual for a given type of aircraft.

The graphic model of the aircraft trajectory, determined on the basis of recorded flight parameters in the on-board recorder, can be useful to assess the quality of the performance of piloting figures as an element of the aviation training.

The above examples demonstrate the necessity of using data from flight parameter on-board recorders and the construction of a proper module in SI TURAWA in order to analyse the flight and support the safe aviation training management.

\section{References:}

[1] Babak, V.P. Caraczenko, V. O. Maksimow and others. Edited by Babak V.P.: Bezpieka Awiacji [Aviation Security Services]: - Kiev, Technika [Technology], 2004.

[2] Bartosiewicz J., Stelmach A.: Problematyka przetwarzania parametrów uzyskanych z pokładowych rejestratorów eksploatacyjnych lotu [The issue of processing the parameters obtained from on-board flight operational recorders]. Prace Naukowe Politechniki Warszawskiej [Scientific works of the Warsaw University of Technology], of 1032014.

[3] Dygnatowski S.: Badanie podatności szkoleniowej systemu statek powietrzny - pilot na przykładzie samolotu mig-29 Praca doktorska [Study of the training susceptibility of the aircraft - pilot system on the basis of mig-29 aircraft. Ph.D. dissertation]. Warsaw 2010.

[4] Instrukcja funkcjonowania systemu obiektywnej kontroli lotów w lotnictwie Sił Zbrojnych RP [Manual of the objective flight control system operation in the Polish Armed Forces aviation]. Warsaw 2013.

[5] Instrukcja bezpieczeństwa lotów Lotnictwa Sił Zbrojnych Rzeczypospolitej Polskiej [Flight safety instructions of the Polish Armed Forces aviation], MON [Ministry of National Defence] 2015.

[6] Witkowski R.: System gromadzenia i przetwarzania danych z pokładowych rejestratorów parametrów lotu na przykładzie PLL "LOT” S.A. [System of collecting and processing data from flight parameter on-board recorders on the basis PLL "LOT" S.A.]; stara.gorpol. pl/galeria/cz-skrzynki/referat.

[7] Zieja M., Smoliński H., Gołda P.: Proactive methods - new quality in aircraft flight safety management. Journal of KONBiN T4 (36) 2015. 


\section{ZARZĄDZANIE PROCESEM SZKOLENIA PILOTÓW WOJSKOWYCH NA PODSTAWIE ANALIZY I OCENY PARAMETRÓW LOTU Z REJESTRATORÓW POKŁADOWYCH}

\section{Wprowadzenie}

Informacja zarejestrowana przez pokładowe rejestratory parametru lotów może być wykorzystana po jej odtworzeniu do różnych celów (rys.1). Pierwszym z nich jest analiza eksploatacyjna. Służy ona przede wszystkim do wykrycia niebezpiecznych faz lotu, co najczęściej wiąże się z przekroczeniem wartości krytycznych najważniejszych parametrów lotu lub ich niekorzystną kombinacją. Dla każdego typu statku powietrznego (SP) jest to zbiór kilkudziesięciu algorytmów, których zakres można najogólniej podzielić na dwie kategorie. Pierwsza kategoria algorytmów dotyczy bezpośrednio bezpieczeństwa wykonanej operacji lotniczej. Wykrycie przekroczenia $\mathrm{w}$ tej kategorii oznacza konieczność podjęcia kolejnych działań przez służbę bezpieczeństwa lotów. Może to być dodatkowy przegląd SP po twardym lądowaniu lub przekroczeniu dozwolonych prędkości lotu, odpowiednich obciążeń, parametrów silnikowych itp. Analizą takiego przypadku zajmują się zarówno osoby związane z obsługą techniczną, jak i osoby z obszaru bezpieczeństwa lotniczego i metodyki szkolenia lotniczego.

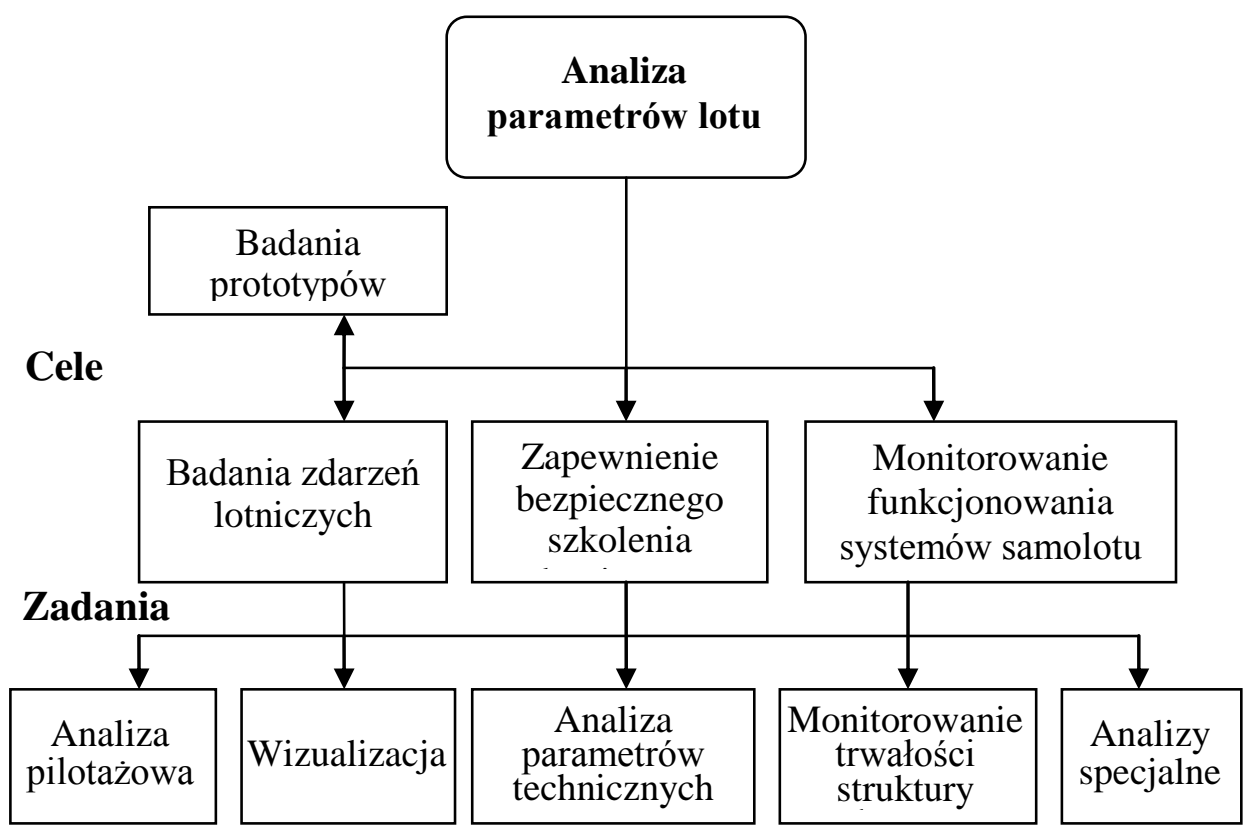

Rys. 1. Schemat funkcjonalny analizy parametrów lotu w lotnictwie wojskowym 
Management of the training process of military pilots ...

Zarzadzanie procesem szkolenia pilotów wojskowych...

Służby inżynieryjne sprawdzają stan SP po zaistnieniu przekroczenia, specjaliści od techniki pilotażu prowadzą działania profilaktyczne i metodyczne wśród personelu latającego.

Druga kategoria to typowe przekroczenia pilotażowe, których efekty mają drugorzędny wpływ na stan eksploatacyjny SP i są związane z błędami w pilotowaniu SP,. zbyt duże odchyłki w ścieżce podejścia do lądowania, bądź niewłaściwe konfiguracje SP w różnych stanach lotu.

Naruszenie zasad bezpiecznego wykonania operacji to również stany lotu bliskie przeciągnięcia, czy zbyt szybkie zbliżanie się do ziemi. Te przekroczenia, (w przeciwieństwie do pierwszych) nie mają bezpośredniego wpływu na pogorszenie własności SP, jednakże mogą one prowadzić do powstania bardzo niebezpiecznych stanów lotu, a w efekcie do katastrofy. Przypadki takie analizowane są przez służbę bezpieczeństwa lotów i służbę szkolenia lotniczego [2], [4], [5], [6], [7].

\section{Analiza lotu samolotu Mig-29 podezas wykonywania figur pilotażowych}

Analizę figur pilotażowych samolotu Mig-29 na podstawie rzeczywistych zapisów $\mathrm{z}$ pokładowych urządzeń rejestracji danych $\mathrm{w}$ czasie lotu przeprowadzono dla ćwiczenia 19 według Programu Szkolenia Bojowego Lotnictwa Myśliwskiego (PSzBLM) wykonywanego przez pilotów o różnej podatności szkoleniowej [3].

Ćwiczenie numer 19 według PSzBLM składa się z elementów pilotażowych, których poprawne wykonanie jest jedną z bardziej skomplikowanych czynności w dziedzinie pilotażu. W trakcie lotu wykonuje się:

- start na dopalaniu z wykonaniem immelmana (opcjonalnie);

- wiraż na dopalaniu na wysokości $1000 \mathrm{~m}$;

- zniżanie do wysokości $500 \mathrm{~m}$;

- wiraż na maksymalnym zakresie pracy silnika;

- zniżanie do wysokości $200 \mathrm{~m}$;

- zakręty o kąt 90 stopni z przechyleniem $45^{\circ}$;

- rozpędzanie do prędkości niezbędnej do wprowadzenia w górkę;

- górkę po kątem $45^{\circ}$;

- nurkowanie pod kątem $45^{\circ}$;

- zwrot bojowy (wg krzywej pętli);

- półprzewrót z doprowadzeniem do krzywej pętli;

- półprzewrót $\mathrm{z}$ doprowadzeniem do lotu poziomego;

- krzywą pętlę z doprowadzeniem do lotu poziomego;

- zwrot bojowy;

- przewrót z doprowadzeniem do lotu poziomego; 
- pętlę z doprowadzeniem do lotu poziomego;

- Immelmana;

- lądowanie po kręgu na wysokości $200 \mathrm{~m}$.

Analizie figur pilotażowych poddano loty, które wykonano w ramach procesu szkolenia lotniczego w następujących warunkach:

- liczba lotów w okresie szkolenia - 2 .

- czas lotu - $30 \mathrm{~min}$.

- cel ćwiczenia: Nauczyć (sprawdzić) pilota wykonywania figur średniego pilotażu na małych wysokościach.

- warunki wykonania: zwykłe warunki atmosferyczne (ZWA) z widzialnością horyzontu naturalnego.

- zakres wysokości: 500 - $3500 \mathrm{~m}$

Analizę porównawczą przeprowadzono na podstawie materiałów z obiektywnej kontroli lotów dla 3 pilotów o różnym stopniu przyswajalności nawyków pilotażowych. (rys. 2 - 16.)

Oznaczenia parametrów występujących w materiałach z obiektywnej kontroli lotu i poddanych deszyfracji za pomocą systemu THETYS IV w systemie obiektywnej kontroli lotów (OKL) zostały przedstawione w tabeli 1.

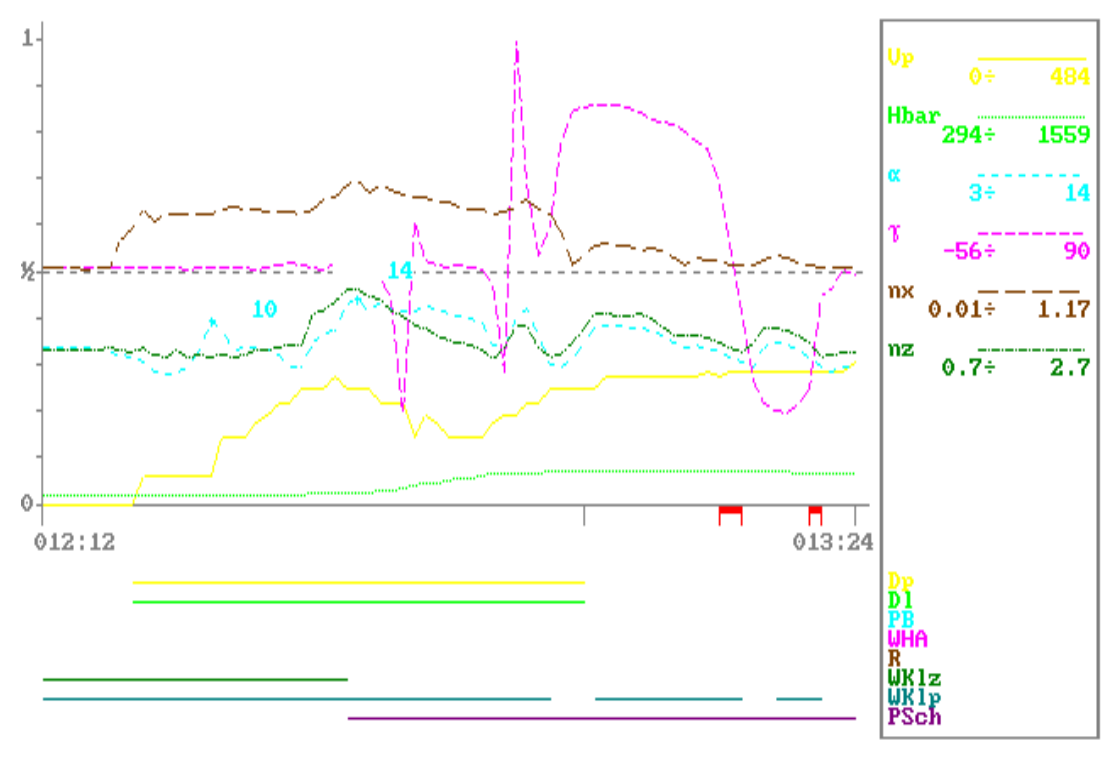

MiG-29U 4615 WYLOT:3 CWICZENIE:0019

Rys. 2. Start na dopalaniu wykonany przez pilota $\mathrm{nr} 1$ 
Management of the training process of military pilots ...

Zarzadzanie procesem szkolenia pilotów wojskowych...

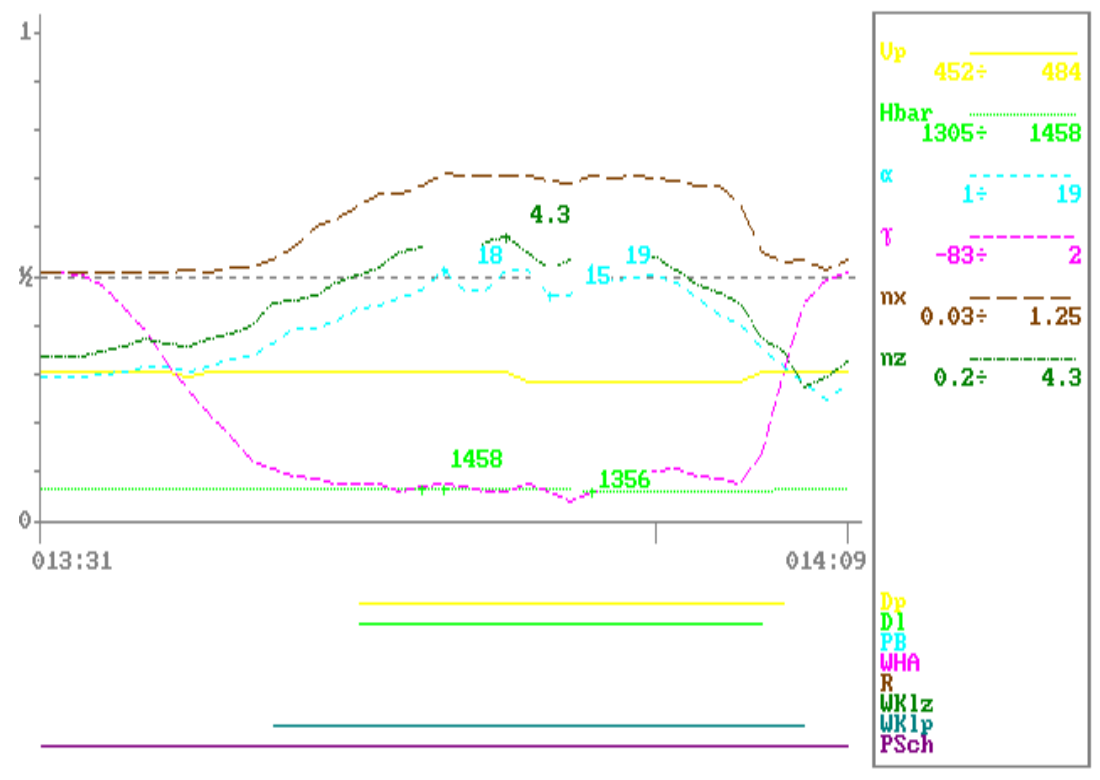

MiG-29U 4615 WYLOT:3 CWICZENIE:0019

Rys. 3. Wiraż na dopalaniu wykonany przez pilota $\mathrm{nr} 1$

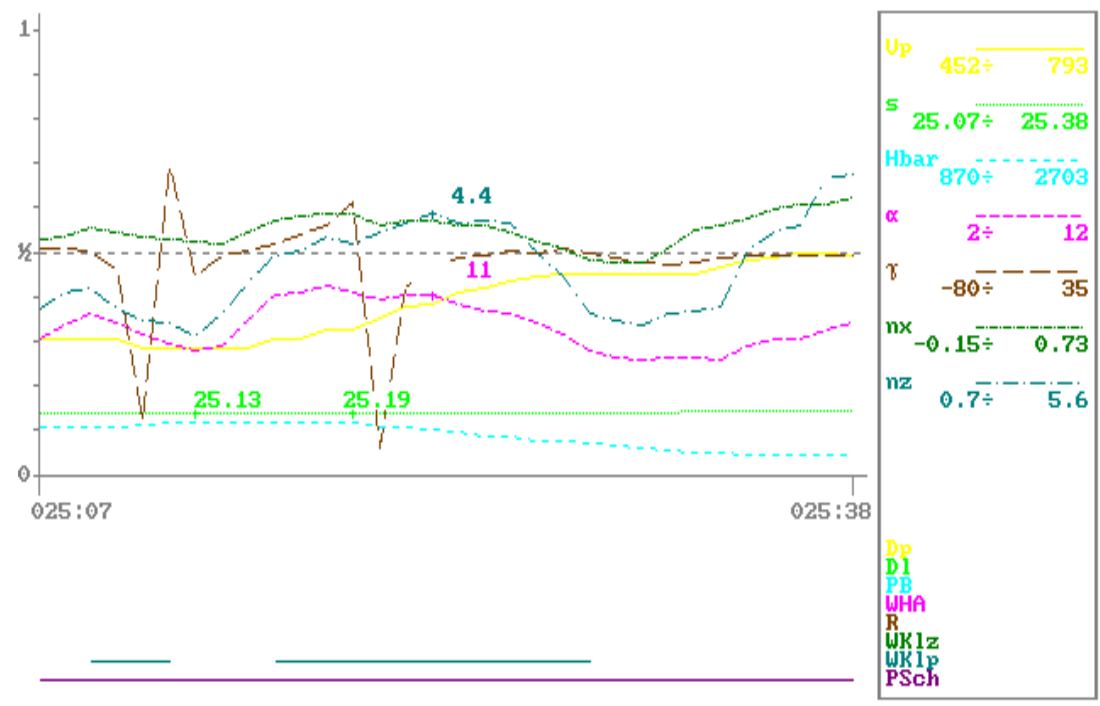

MiG-29U 4615 WYLOT:3 CWICZENIE:0019

Rys. 4. Przewrót wykonany przez pilota $\mathrm{nr} 1$ 


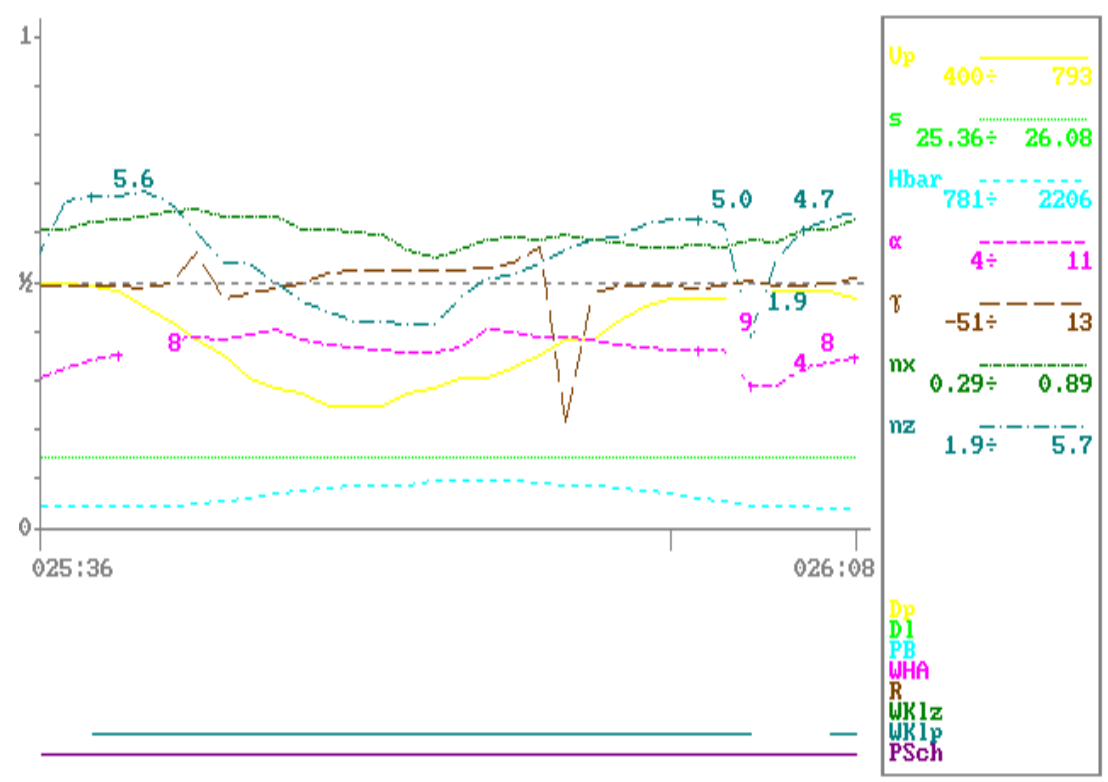

\section{MiG-29U 4615 WYLOT:3 CWICZENIE:0019}

Rys. 5. Pętla wykonana przez pilota $\mathrm{nr} 1$

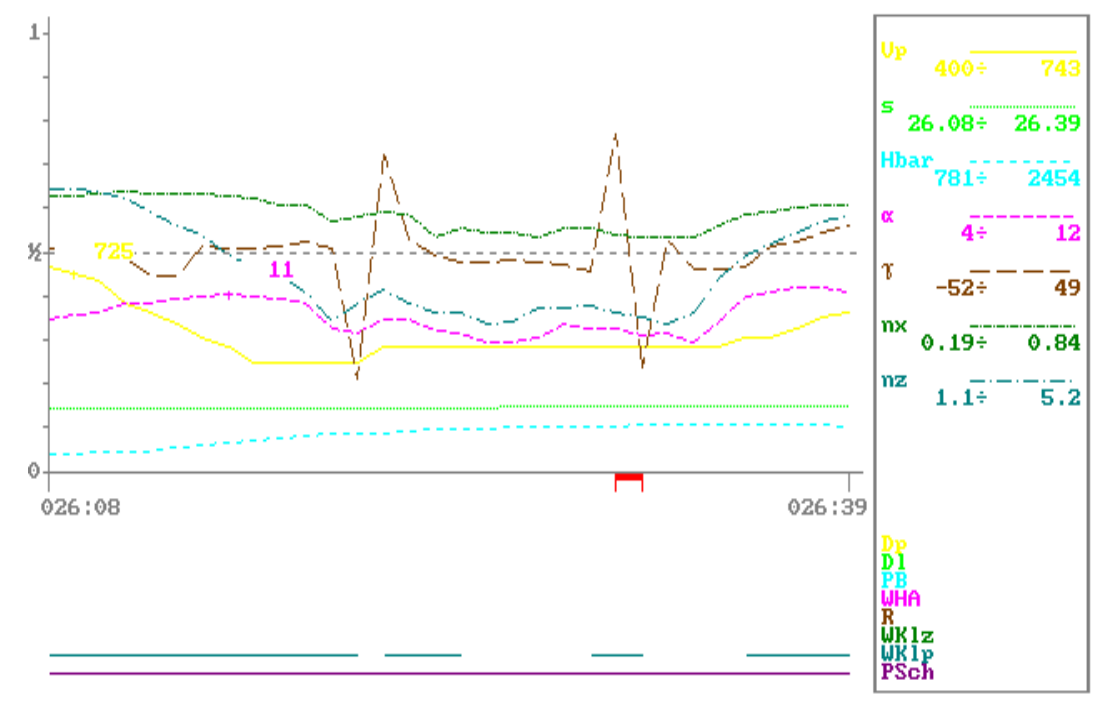

MiG-29U 4615 WYLOT:3 $\quad$ CWICZENIE:0019

Rys. 6. Immelman wykonany przez pilota $\mathrm{nr} 1$ 
Management of the training process of military pilots ...

Zarzadzanie procesem szkolenia pilotów wojskowych...

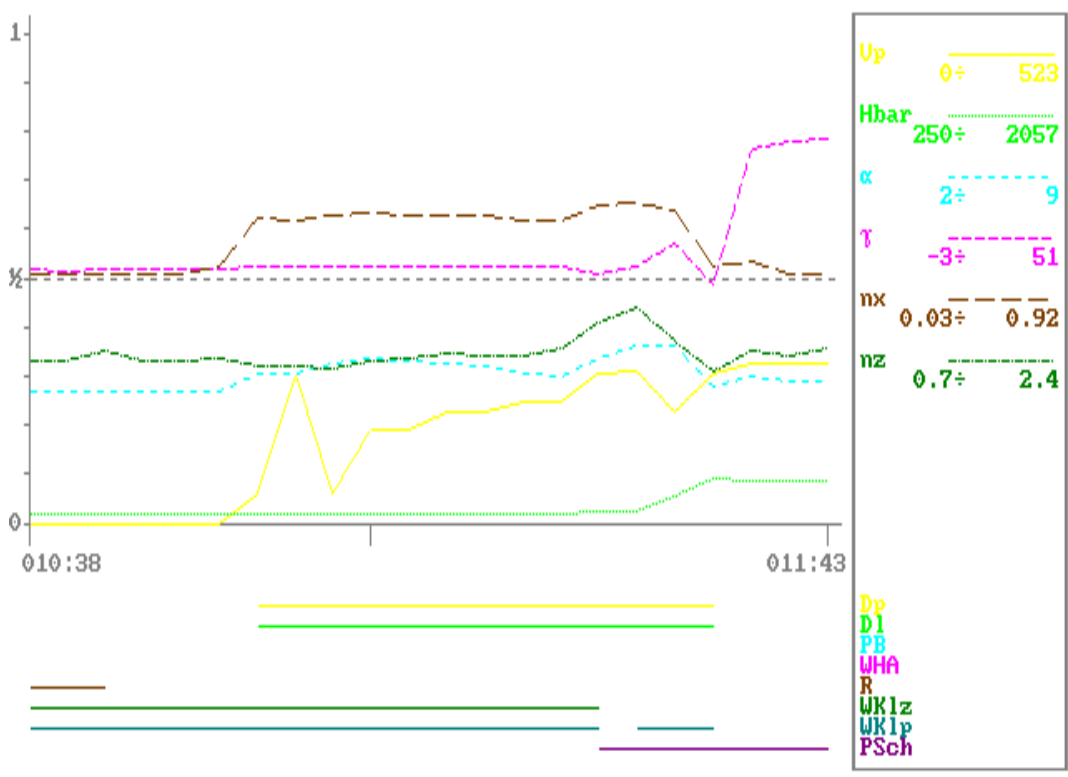

MiG-29U 4615 WYLOT:2 CWICZENIE:0019

Rys. 7. Start na dopalaniu wykonany przez pilota $n r 2$

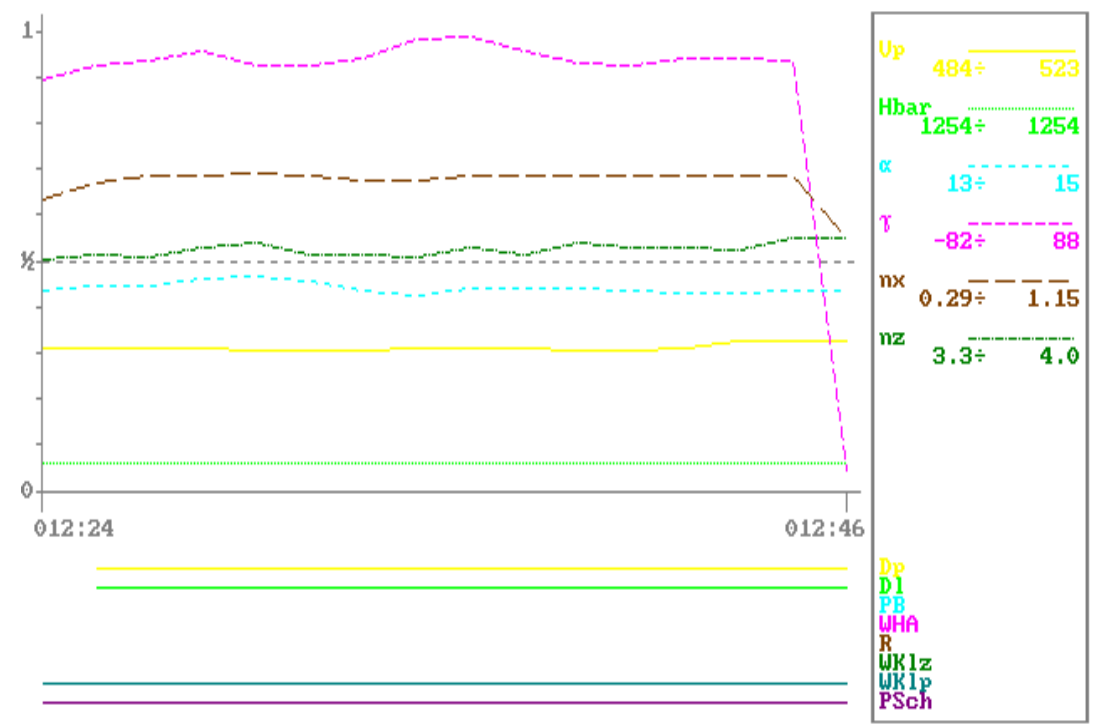

MiG-29U 4615 WYLOT:2 CWICZENIE:0019

Rys. 8. Wiraż na dopalaniu wykonany przez pilota $\mathrm{nr} 2$ 
Mariusz Zieja, Henryk Smoliński, Pawet Gotda
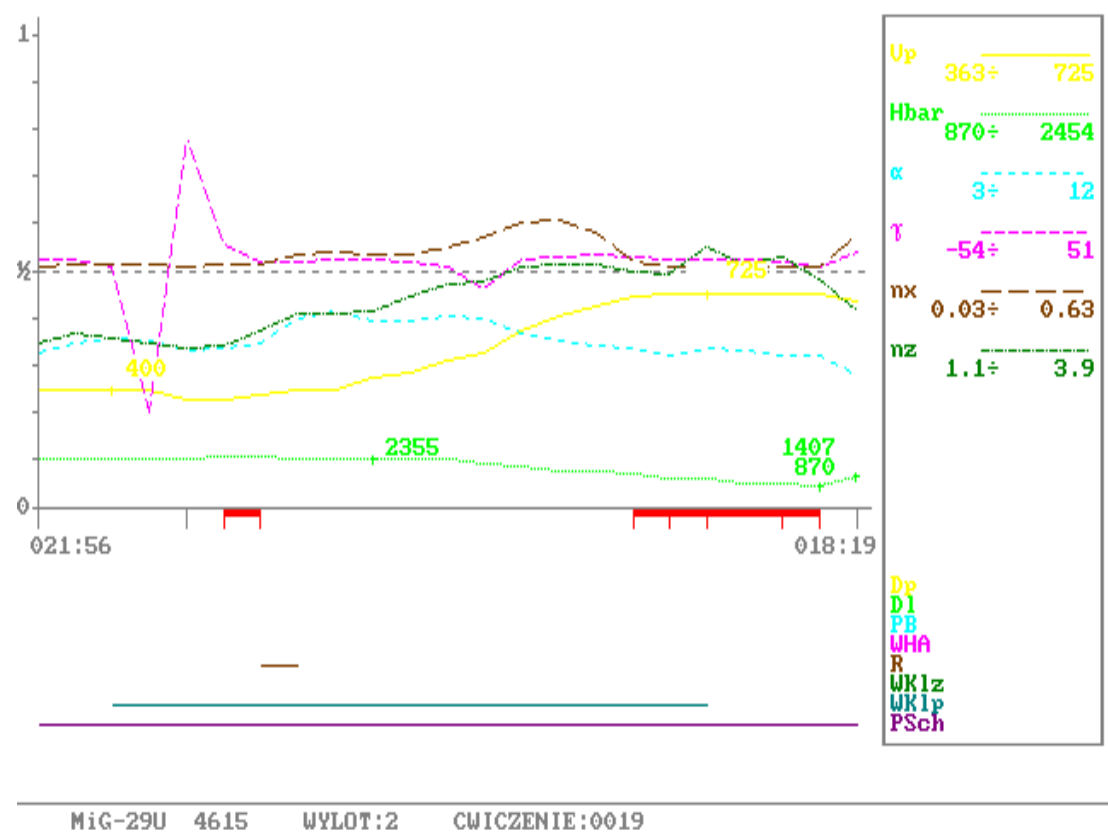

Rys. 9. Przewrót wykonany przez pilota $n r 2$

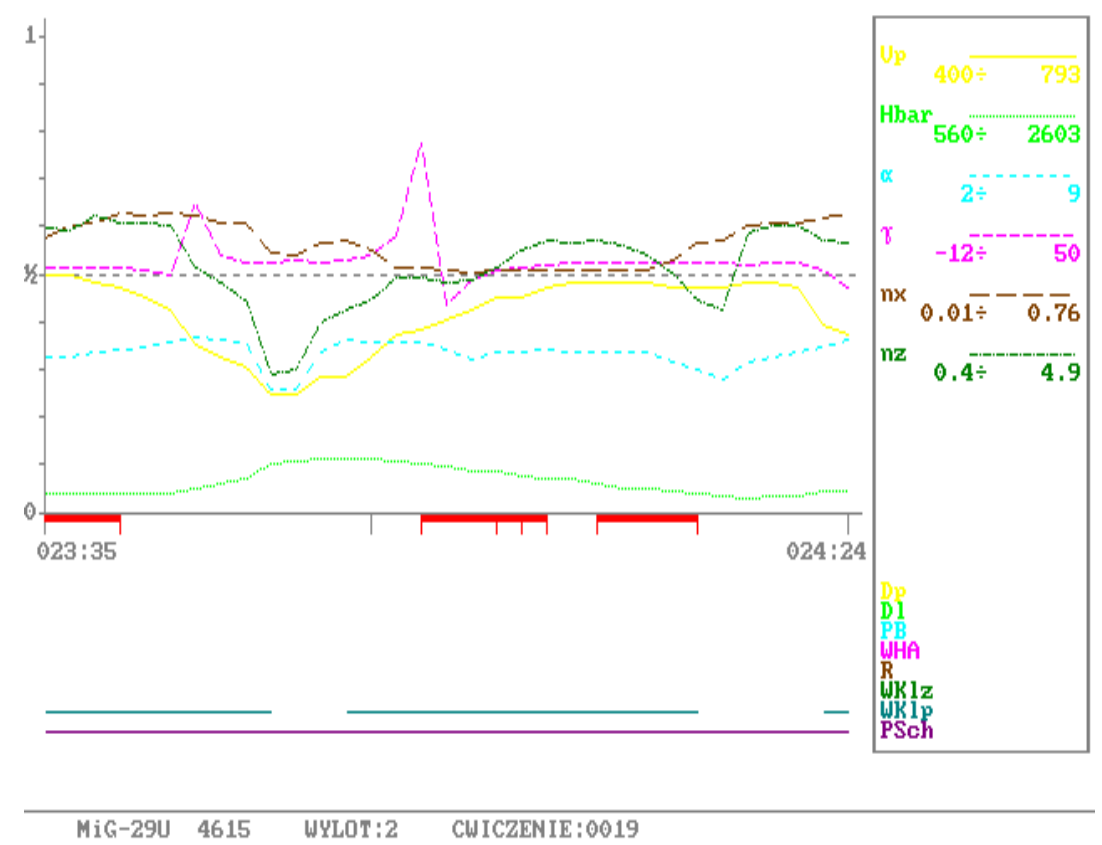

Rys. 10. Pętla wykonana przez pilota $n r 2$ 
Management of the training process of military pilots ...

Zarzadzanie procesem szkolenia pilotów wojskowych...

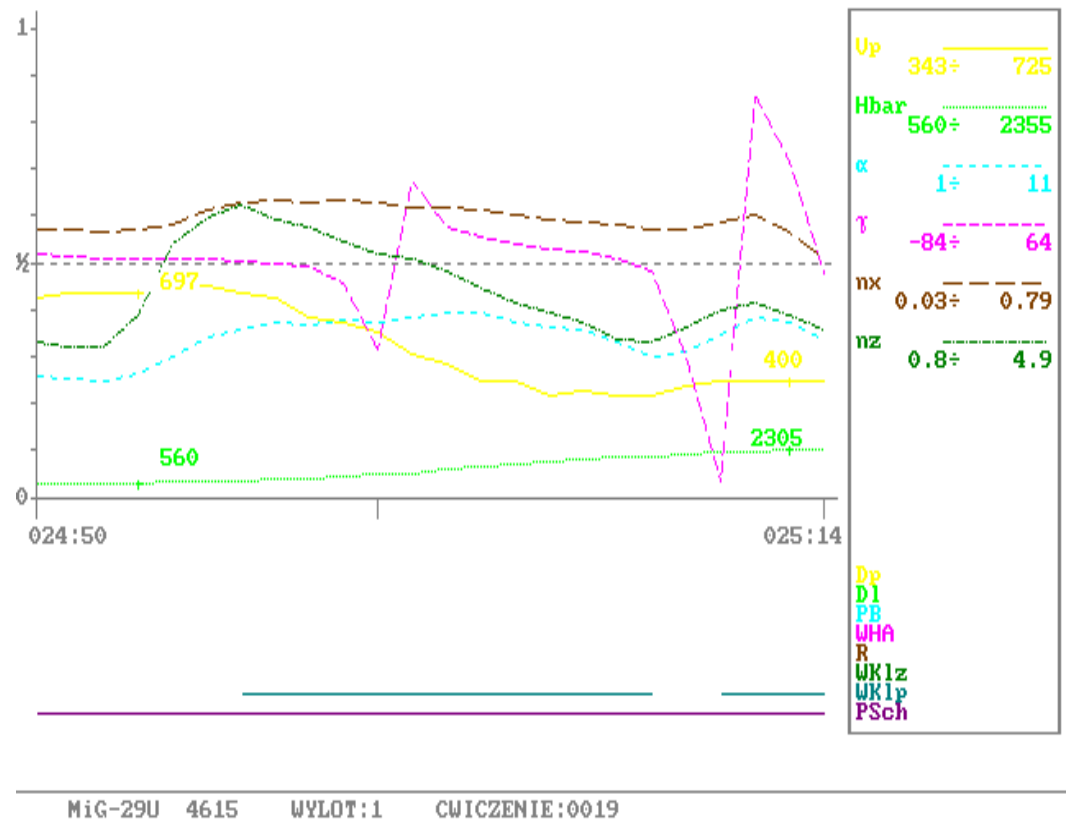

Rys. 11. Immelman wykonany przez pilota $\mathrm{nr} 2$

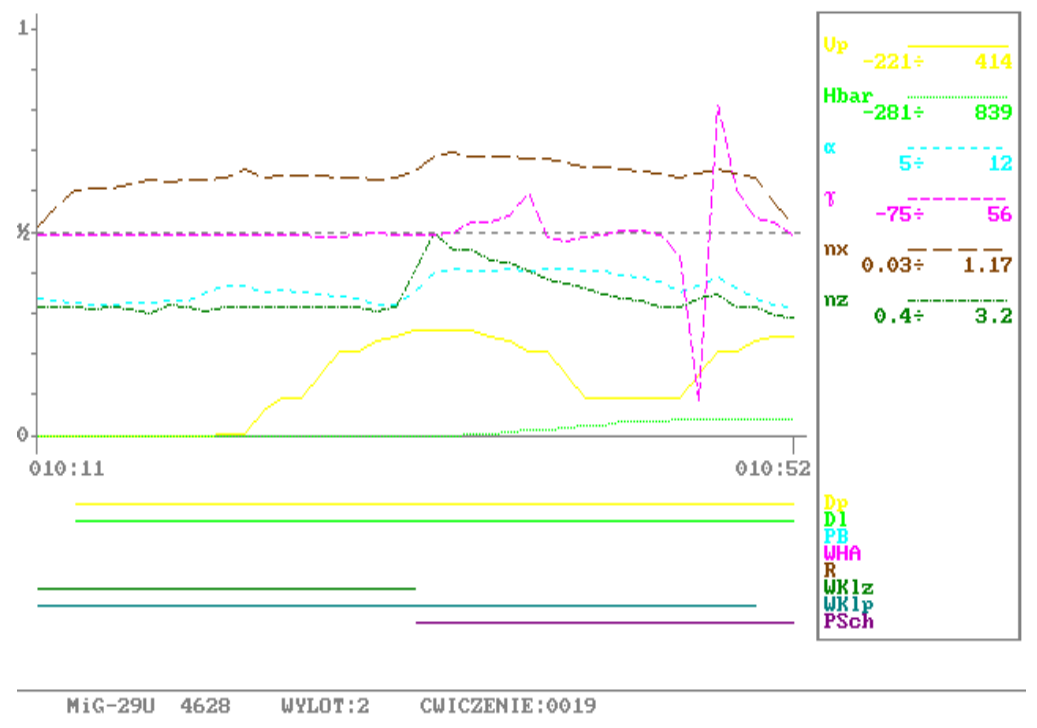

Rys. 12. Start na dopalaniu wykonany przez pilota $\mathrm{nr} 3$ 


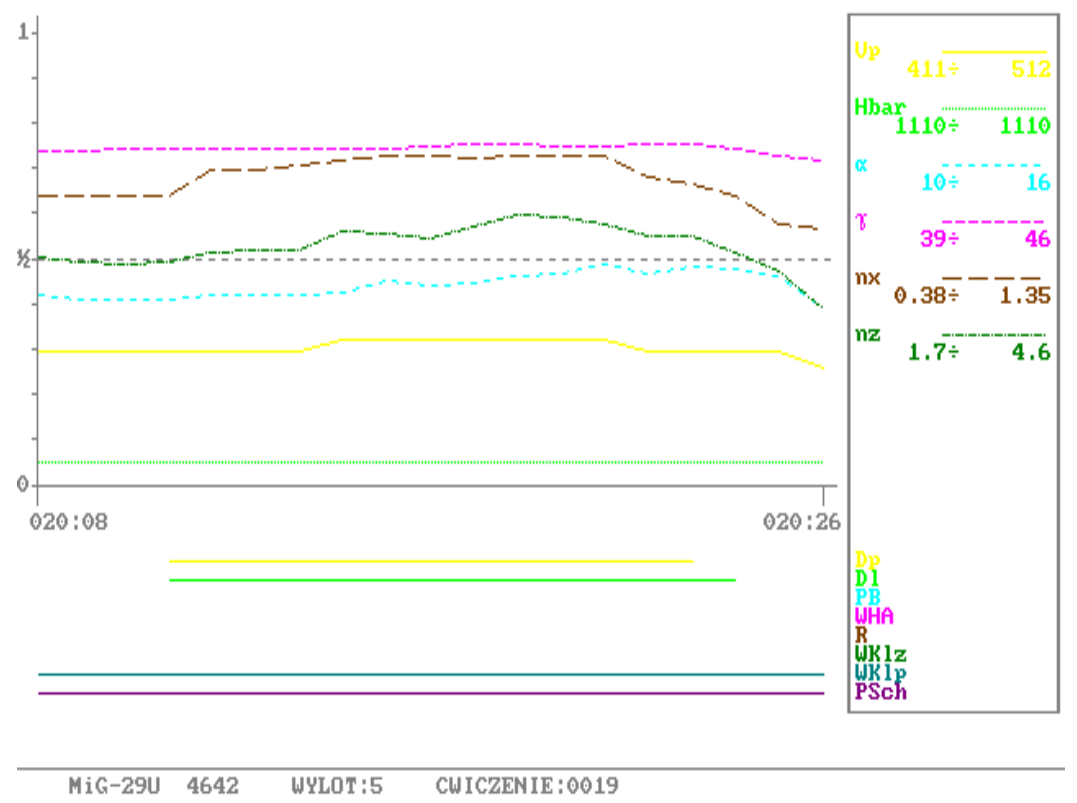

Rys. 13. Wiraż na dopalaniu wykonany przez pilota $n r 3$

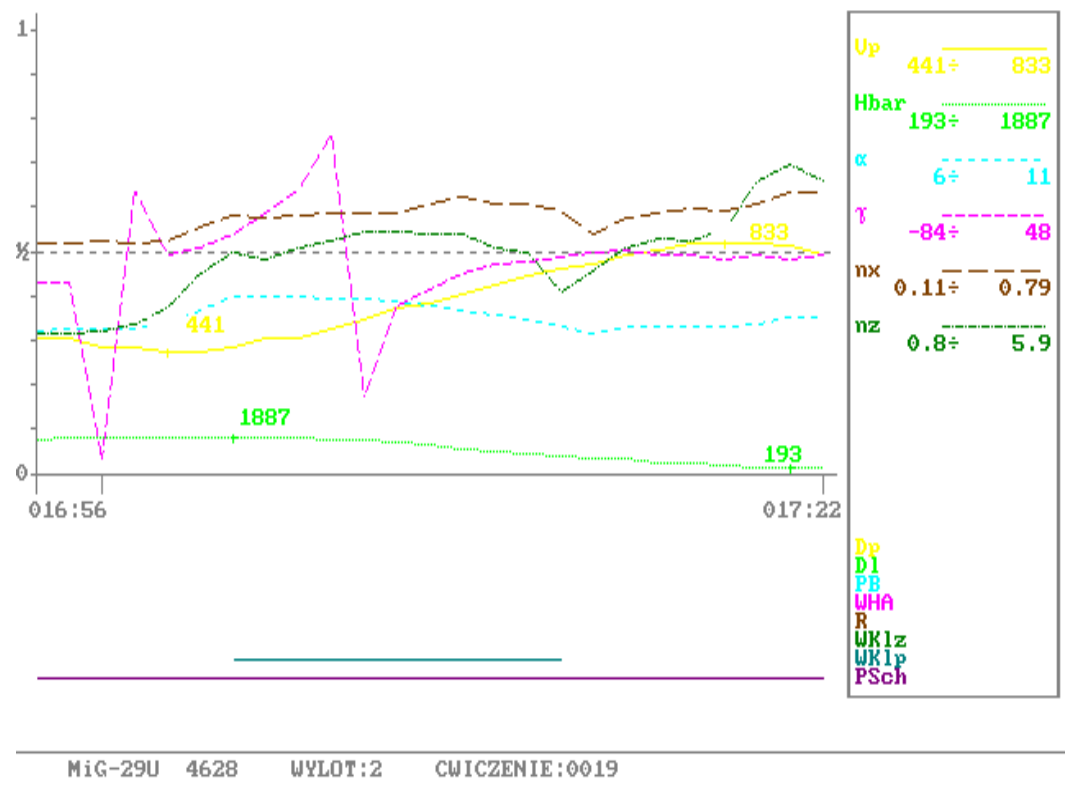

Rys. 14. Przewrót wykonany przez pilota nr 3 
Management of the training process of military pilots ...

Zarzadzanie procesem szkolenia pilotów wojskowych...

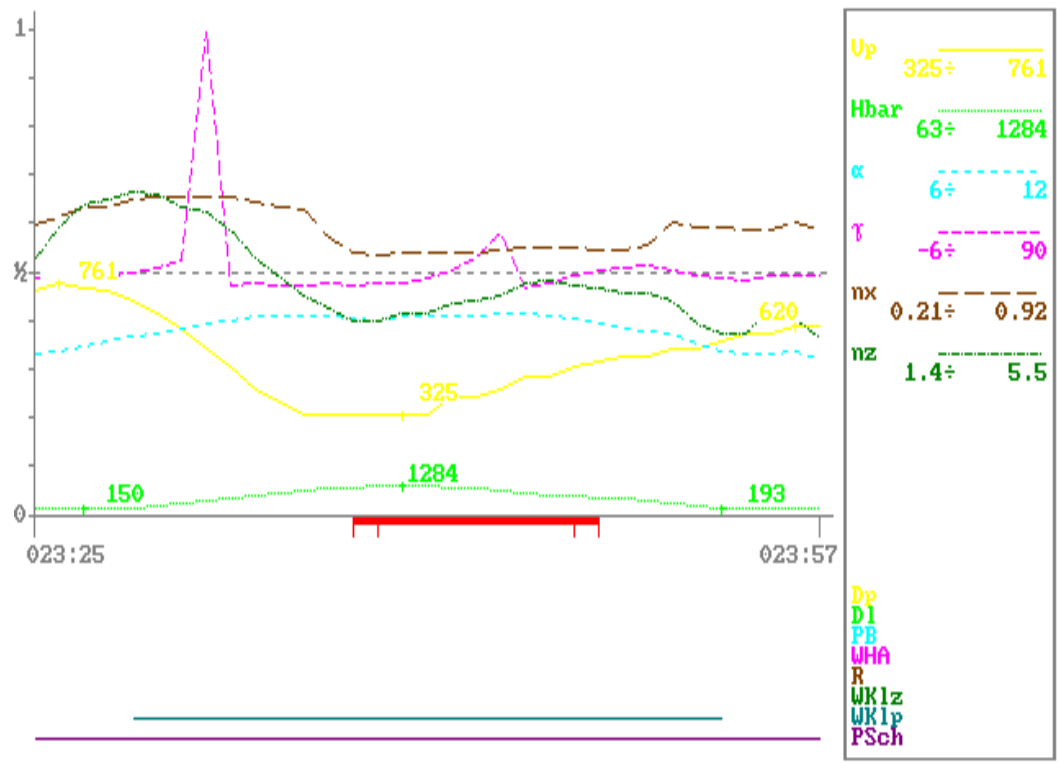

$\begin{array}{llll}\text { MiG-29U } & 4628 & \text { WYLOT:2 } & \text { CWICZENIE: } 0019\end{array}$

Rys. 15. Pętla wykonana przez pilota $\mathrm{nr} 3$

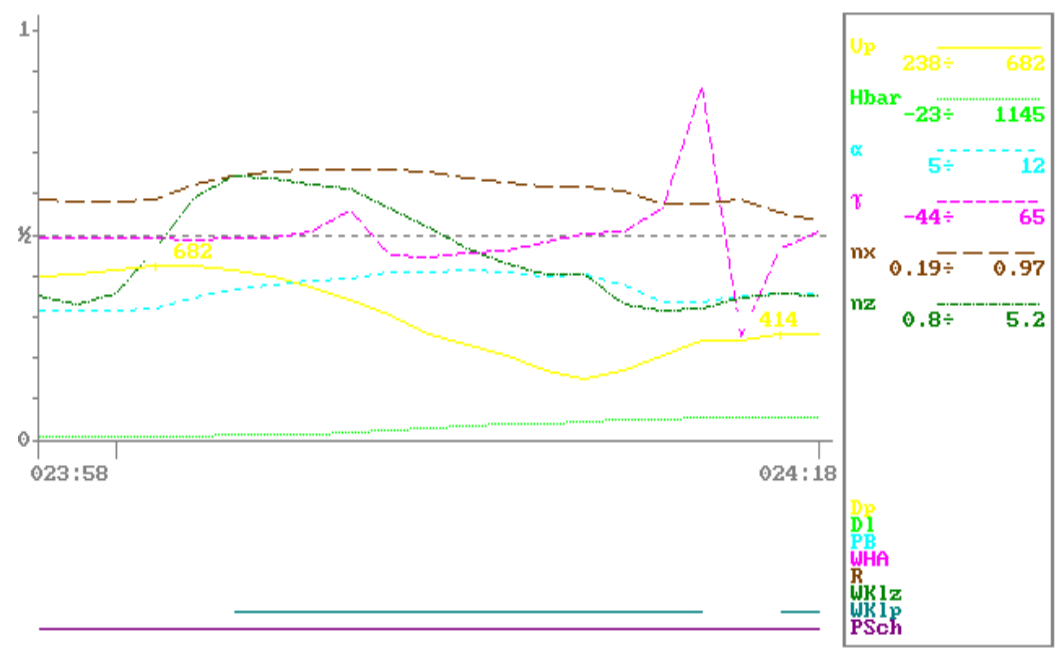

MiG-29U 4628 WYLOT:2 $\quad$ CWICZENIE:0019

Rys. 16. Immelman wykonany przez pilota $\mathrm{nr} 3$ 
Tabela 1. Oznaczenia parametrów dla materiałów z OKL poddanych analizie porównawczej

\begin{tabular}{|c|c|c|c|}
\hline Parametr & Rodzaj zapisu & Kolor & $\begin{array}{c}\text { Zakres } \\
\text { (na podstawie programu THETYS } \\
\text { IV dla Mig }-29 \text { ) } \\
\end{array}$ \\
\hline $\mathbf{V p}$ & Analogowy & Żółty & $0-2450 \mathrm{~km} / \mathrm{h}$ \\
\hline Hbar & Analogowy & Zielony & $0-22000 \mathrm{~m}$ \\
\hline Alfa & Analogowy & Niebieski & $-2-22^{0}$ \\
\hline Gamma & Analogowy & Różowy & $-90-90^{0}$ \\
\hline $\mathbf{N x}$ & Analogowy & Brązowy & $-3-3 g$ \\
\hline $\mathbf{N z}$ & Analogowy & $\begin{array}{l}\text { Ciemna } \\
\text { zieleń }\end{array}$ & $-3,5-10 \mathrm{~g}$ \\
\hline Dp & Binarny & Żółty & Dopalacz lewego silnika \\
\hline DL & Binarny & Zielony & Dopalacz prawego silnika \\
\hline PB & Binarny & Niebieski & Przycisk bojowy \\
\hline WHA & Binarny & Różowy & $\begin{array}{l}\text { Wypuszczony hamulec } \\
\text { aerodynamiczny }\end{array}$ \\
\hline WKLz & Binarny & Brązowy & Wychylone klapy zaskrzydłowe \\
\hline WKLp & Binarny & $\begin{array}{l}\text { Ciemna } \\
\text { zieleń }\end{array}$ & Wychylone klapy przednie \\
\hline PSch & Binarny & Fioletowy & Podwozie schowane \\
\hline
\end{tabular}

Wyniki przeprowadzonej analizy figur pilotażowych samolotu Mig-29 na podstawie materiałów OKL zostały przedstawione w tabeli 2 . 
Management of the training process of military pilots ...

Zarzadzanie procesem szkolenia pilotów wojskowych...

Tabela 2 Analiza porównawcza figur pilotażowych samolotu Mig-29 na podstawie materiatów $O K L$

\begin{tabular}{|c|c|c|c|c|}
\hline $\mathrm{Lp}$ & $\begin{array}{l}\text { Rodzaj } \\
\text { figury }\end{array}$ & $\begin{array}{c}\text { Pilot nr } 1 \\
\text { Uwagi }\end{array}$ & $\begin{array}{c}\text { Pilot nr } 2 \\
\text { Uwagi }\end{array}$ & $\begin{array}{c}\text { Pilot nr } 3 \\
\text { Uwagi }\end{array}$ \\
\hline 1 & $\begin{array}{l}\text { Start na } \\
\text { dopalaniu / } \\
\text { wykonanie } \\
\text { Immelmana }\end{array}$ & $\begin{array}{l}\text { Oderwanie samolotu na } \alpha-10^{\circ} \\
\text { następnie wznoszenie do } \\
\text { wysokości } 200 \mathrm{~m} \text { (prędkość } \\
\text { wznoszenia } 134 \mathrm{i} .1-2 \mathrm{~m} / \mathrm{s}) \mathrm{i} \\
\text { rozpoczęcie wykonania figury } \\
\text { Immelmana - (Rys. 1). }\end{array}$ & $\begin{array}{l}\text { Oderwanie samolotu i } \\
\text { rozpędzanie w locie } \\
\text { pozio-mym do Vp ok. } \\
450 \mathrm{~km} / \mathrm{h} \text {, następnie } \\
\text { rozpoczęcie wykona- } \\
\text { nia figury Immelmana. } \\
\text { Figura nie kończy się } \\
\text { płynną półbeczką - } \\
\text { (Rys 6). }\end{array}$ & $\begin{array}{l}\text { Wykonany } \\
\text { prawidłowo } \\
\text { - (Rys. 11). }\end{array}$ \\
\hline 2 & $\begin{array}{l}\text { Wiraż na } \\
\text { dopalaniu }\end{array}$ & $\begin{array}{l}\text { Wiraż nie został wykonany w } \\
\text { sposób płynny - ze zmiennym } \\
\text { przeciążeniem } \mathrm{n}_{\mathrm{z}} \mathrm{i} \alpha \text { oraz z utratą } \\
\text { wysokości - (Rys. } 2)\end{array}$ & $\begin{array}{l}\text { Wiraż wykonany w } \\
\text { sposób płynny - } \\
\text { (Rys. 7). }\end{array}$ & $\begin{array}{l}\text { Wykonany } \\
\text { prawidłowo } \\
\text { - (Rys. 12). }\end{array}$ \\
\hline 3 & Przewrót & $\begin{array}{l}\text { Pomiędzy obrotem samolotu o } \\
180^{0} \text { (półbeczką) a dalszą fazą } \\
\text { figury występuje przerwa } \\
\text { czasowa } 5 \text { sek. Przerwa powoduje } \\
\text { spadek wysokości wprowadzenia } \\
\text { - (Rys. 3) }\end{array}$ & $\begin{array}{l}\text { Po wyprowadzeniu z } \\
\text { przewrotu pilot nie } \\
\text { doprowadza do lotu } \\
\text { poziomego - (Rys. } \\
\text { 8). }\end{array}$ & $\begin{array}{l}\text { Wykonany } \\
\text { prawidłowo } \\
-(\text { Rys. 13). }\end{array}$ \\
\hline 4 & Pętla & $\begin{array}{l}\text { Pętla pionowa wykonana zbyt } \\
\text { ciasno. W końcowej fazie figury } \\
\text { następuje chwilowe oddanie } \\
\text { drążka w celu osiągnięcia } \\
\text { nakazanej wysokości zakończenia } \\
\text { pętli. Powoduje to krótkotrwałą } \\
\text { desta-bilizację lotu oraz } \\
\text { zmniejszenie przeciążenia } n_{\mathrm{z}} \text { i } \alpha- \\
\text { (Rys. 4) }\end{array}$ & $\begin{array}{l}\text { Pierwsza część pętli } \\
\text { (wznoszenie) wyko- } \\
\text { nana ciaśniej niż } \\
\text { druga. Po zakończe- } \\
\text { niu pętli pilot znów } \\
\text { nie doprowadza do } \\
\text { lotu poziomego - } \\
\text { (Rys. 9). }\end{array}$ & $\begin{array}{l}\text { Wykonany } \\
\text { prawidłowo } \\
\text { - (Rys. 14). }\end{array}$ \\
\hline 5 & Immelman & $\begin{array}{l}\text { Wprowadzenie do immelmana } z \\
\text { Vp }=700 \text {. Immelman wykonany } \\
\text { prawidłowo-(Rys 5) }\end{array}$ & $\begin{array}{l}\text { Immelman wykonany } \\
\text { prawidłowo - (Rys } \\
10) \text {. }\end{array}$ & $\begin{array}{l}\text { Wykonany } \\
\text { prawidłowo } \\
\text {-(Rys. 15). }\end{array}$ \\
\hline \multirow[t]{2}{*}{6} & \multirow[t]{2}{*}{ Uwagi } & $\begin{array}{l}\text { Prezentowane ćwiczenie pilot } \\
\text { wykonywał jeszcze trzykrotnie z } \\
\text { różnymi instruktorami wykonując } \\
\text { powyższe elementy zarówno z } \\
\text { użyciem dopalania jak i bez. }\end{array}$ & $\begin{array}{l}\text { W kolejnym locie } \\
\text { wszystkie przedsta- } \\
\text { wione figury pilot } \\
\text { wykonał prawidłowo } \\
\text { zarówno na zakresie } \\
\text { dopalania, jak i na } \\
\text { zakresie maksymal- } \\
\text { nych obrotów silnika. }\end{array}$ & \\
\hline & & $\begin{array}{l}\text { Na podstawie analizy materiałów } \\
\text { OKL można jednoznacznie } \\
\text { stwier-dzić, że wszystkie figury } \\
\text { lub mane-wry z użyciem } \\
\text { dopalania sprawiały pilotowi } \\
\text { pewne trudności. }\end{array}$ & $\begin{array}{l}\text { W kolejnych lotach } \\
\text { pilot wykonywał } \\
\text { wszystkie figury w } \\
\text { sposób prawidłowy. }\end{array}$ & \\
\hline
\end{tabular}




\section{Analiza lotu samolotu podczas wykonywania figur pilotażowych z wykorzystaniem modelu graficznego}

\section{Obliczanie toru lotu samolotu}

Jeżeli rejestrator pokładowy umożliwia rejestrowanie prędkości wg przyrządu i położenie kątowe SP to do obliczenia toru lotu wykonuje się następujące czynności [1]:

1) Określa się rzeczywistą prędkość lotu w prędkościowym układzie współrzędnych. Ponieważ system rejestracji zapisuje prędkość wg przyrządów w prędkościowym układzie współrzędnych, trzeba skorygować prędkość wg przyrządu stosując poprawki dla otrzymania prędkości indykatorowej

$$
V_{i}=V_{p r z}+\delta V_{a}+\delta V_{i n s t r}+\delta V_{s t},
$$

Gdzie:

$\mathrm{V}_{\mathrm{prz}} \quad$ - prędkość wg przyrządów, zarejestrowana środkami pokładowymi;

$\delta V_{a} \quad$ - poprawka aerodynamiczna (uwzględnia wskazania czujnika podczas zmiany warunków lotu);

$\delta V_{\text {inst }}$ - poprawka instrumentalna (uwzględnia właściwości konstrukcji i technologiczne niedociągnięcia konstrukcji czujnika);

$\delta V_{s t} \quad$ - poprawka na stałość środowiska.

Wymienione poprawki można znaleźć w instrukcji użytkowania w locie konkretnego typu SP. Z reguły są one funkcjonalnie zależne od wysokości i prędkości lotu i konfiguracji skrzydła samolotu.

2) Obliczamy rzeczywistą prędkość wg prędkości indykatorowej

$$
V_{i c}=V_{i} / \sqrt{\Delta}
$$

Gdzie:

$\Delta$ - stosunek gęstości powietrza na wysokości lotu do gęstości na poziomie morza $\left(\Delta=\rho_{H} / \rho_{0}\right)$. Odpowiednie wartości gęstości powietrza $\rho_{0}, \rho_{H}$ oblicza się zgodnie $\mathrm{z}$ atmosferą wzorcową.

3) Przeliczamy prędkość na osie związanego układu współrzędnych.

$$
\begin{aligned}
& V_{x}=V_{i c} \cos \alpha \cos \beta, \\
& V_{y}=-V_{i c} \sin \alpha \cos \beta ; \\
& V_{z}=V_{i c} \sin \beta ;
\end{aligned}
$$

4) Mając kąty, które charakteryzują położenie SP w przestrzeni $(\vartheta, \gamma, \psi)$, obliczamy rzuty prędkości w normalnym układzie współrzędnych (bez uwzględniania prędkości wiatru). 
Management of the training process of military pilots ...

Zarzadzanie procesem szkolenia pilotów wojskowych...

$V_{x g}^{\prime}=V_{x} \cos \vartheta \cos \psi-V_{y}(\sin \vartheta \cos \gamma \cos \psi-\sin \gamma \sin \psi)+V_{z}(\sin \vartheta \sin \gamma \cos \psi+\cos \gamma \sin \psi) ;$

$$
\begin{gathered}
V_{y g}^{\prime}=V_{x} \sin \vartheta+V_{y} \cos \vartheta \cos \gamma-V_{z} \cos \vartheta \sin \gamma ; \\
V_{z g}^{\prime}=-V_{x} \cos \vartheta \sin \psi+V_{y}(\cos \gamma \cos \psi-\sin \vartheta \sin \gamma \sin \psi) ;
\end{gathered}
$$

5) Korygujemy otrzymane dane na prędkość wiatru wg trajektorii lotu

$$
\begin{aligned}
& V_{x g}=V_{x g}^{\prime}+W_{x g} ; \\
& V_{y g}=V_{y g}^{\prime}+W_{y g} ; \\
& V_{z g}=V_{z g}^{\prime}+W_{z g}
\end{aligned}
$$

6) Całkowanie układu równań $\mathrm{z}$ otrzymanymi rzutami prędkości umożliwia uzyskanie rzutów toru lotu na odpowiednie płaszczyzny.

W tym układzie współrzędnych tor lotu charakteryzuje się rzutami na odpowiednie płaszczyzny (powierzchnie): pionową $O X_{g} Y_{g}$; poziomą $O X_{g} Z_{g}$; boczną $O Y_{g} Z_{g}$. Rzuty położenia samolotu na odpowiednie osie tego układu współrzędnych oblicza się z zależności:

$$
\left.\begin{array}{l}
X_{g}=\int_{t_{1}}^{t_{2}} V_{x g}+X_{g 0} \\
Y_{g}=\int_{t_{1}}^{t_{2}} V_{y g}+Y_{g 0} \\
Z_{g}=\int_{t_{1}}^{t_{2}} V_{g}+Z_{g 0}
\end{array}\right\}
$$

Gdzie:

$\mathrm{t}_{1}$ - wartość czasu od początku którego sporządza się tor lotu;

$\mathrm{t}_{2}$ - końcowa wartość czasu;

$X_{g 0}, Y_{g 0}, Z_{g 0}$ - początkowe wartości parametrów położenia SP w momencie czasu $\mathrm{t}_{1}$;

$V_{x g}, V_{y g}, V_{z g}$ - rzuty prędkości ruchu środka masy samolotu na osie normalnego układu współrzędnych $O X_{g} Y_{g} Z_{g}$.

W zależności od tego, jaki zbiór parametrów ruchu SP jest rejestrowany, możliwe są warianty obliczania prędkości $V_{x g}, V_{y g}, V_{z g}$.

\section{Przykład analizy toru lotu samolotu}

Jako przykład analizy toru lotu samolotu manewrowego podczas wykonywania figur wyższego pilotażu wybrano lot treningowy [1], w którym były wykonywane następujące figury: „beczka”, „wiązanka pętli”, z przewrotem; "pętla”; „pętla z przewrotem”; „wiraż”; „dzwon”, „lot odwrócony” - beczka - lot odwrócony, przewrót na $270^{\circ}$. 
W systemie pokładowym zarejestrowano:

- prędkość wg przyrządów $\mathrm{V}_{\text {prz }}$;

- wysokość lotu (radiowysokościomierz) - H;

- lokalny kąt natarcia $-\alpha_{m}$,

- kąt ślizgu - $\beta$;

- kąt przechylenia - $\gamma$;

- kąt pochylenia - $\vartheta$

- kąt toru lotu - $\psi$; .

Lot, który jest przedmiotem oceny jakości wykonania figur pilotażowych został zrealizowany zgodnie $\mathrm{z}$ z wymaganiami modelu graficznego lotu oraz ograniczeniami eksploatacyjnymi przedstawionymi w instrukcji użytkowania $\mathrm{w}$ locie danego typu samolotu. Analizę porównawczą jakości wykonania figur pilotażowych na podstawie zarejestrowanych danych z pokładowych rejestratorów parametrów lotu, $\mathrm{z}$ wymaganiami instrukcji $\mathrm{i}$ modelu graficznego lotu przedstawiono w tabeli 3 .

Model graficzny lotu - to wykres toru ruchu samolotu podczas wykonywania oddzielnych figur z zaznaczeniem na nim charakterystycznych punktów i wartości parametrów ruchu samolotu w tych punktach. Model graficzny opracowuje się odpowiednio do zadania zadanego pilotowi i jest dla niego podstawowym dokumentem.

Do obiektywnej oceny jakości wykonanych figur obliczono trajektorię lotu wg zależności przedstawionych wyżej. Na rys. 17 pokazano rzut toru ruchu na płaszczyznę pionową.

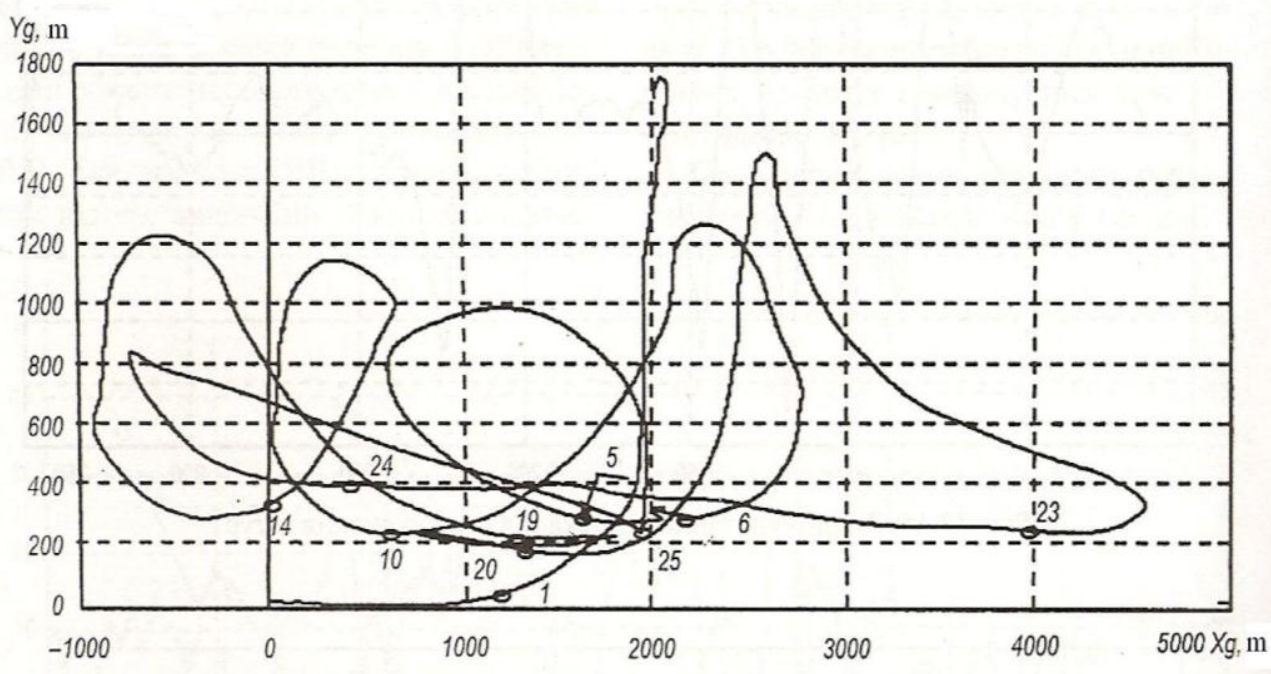

Rys 17. Rzut trajektorii ruchu samolotu na płaszczyzne pionowa [1] 
Management of the training process of military pilots ...

Zarzadzanie procesem szkolenia pilotów wojskowych...

Rzut trajektorii ruchu samolotu na płaszczyznę poziomą przedstawiono na rys. 18. Analiza maksymalnych wartości wysokości oddzielnych figur na płaszczyźnie pokazuje, że są one zgodne $\mathrm{z}$ zapisami wartości wysokości lotu tych figur. Maksymalne bezwzględne uchyby wynoszą w przybliżeniu $40 \mathrm{~m}$ wg wysokości, co odpowiada uchybom zapisu wysokości lotu. Potwierdza to, że tor lotu opracowano prawidłowo.

Na rys. 18 pokazano również punkty, którymi figury wyróżniają się jedna od drugiej. Jest to umowny podział, gdyż one częściowo opierają się o przejściowe odcinki ruchu samolotu, czyli o odcinki rozpędzania i hamowania.

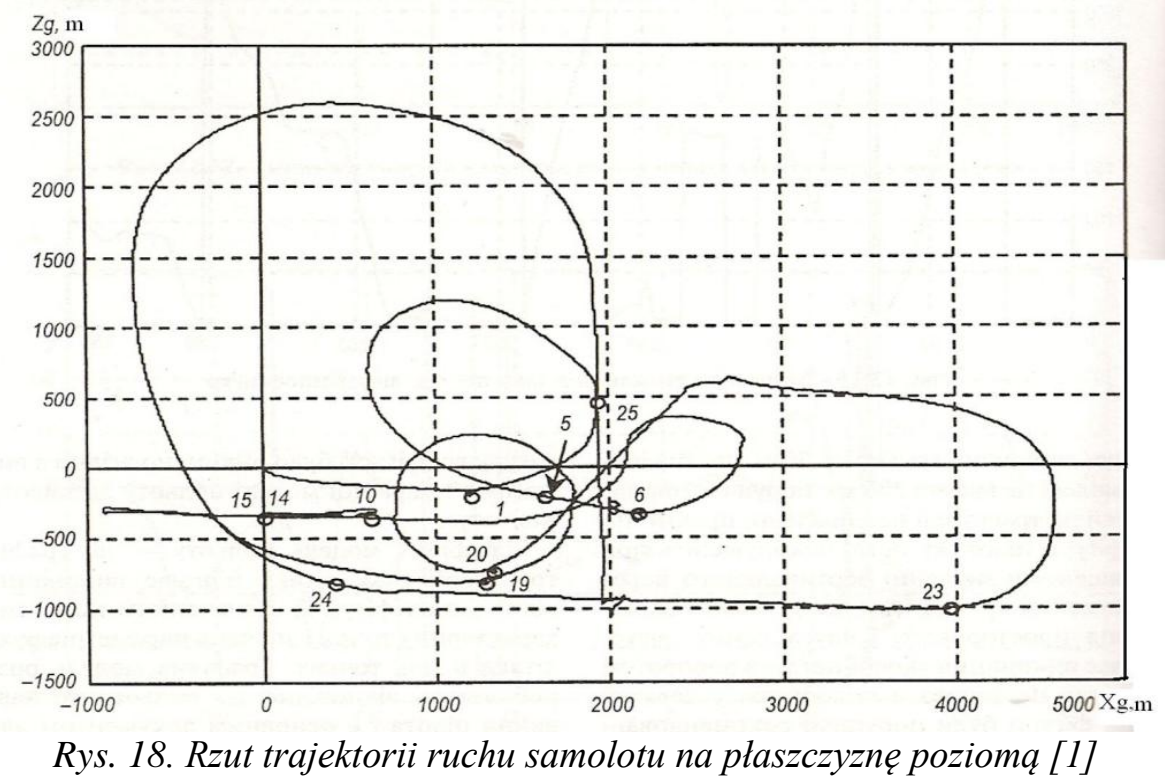

Wyznaczono następujące figury:

1-5 - „Pętla”; 5-6- „,beczka”; 6-10- „pętla z przewrotem”; 10-14- „pętla”; 14-19„pętla z przewrotem”; 19-20- „wiraż”; 20-22- „dzwon”; 23-24- „ lot odwróconybeczka- lot odwrócony"; 24-25- obrót o $270^{\circ}$.

Analiza przedstawionych wyżej wykresów pokazuje, że do realizacji kompletu dziewięciu przedstawionych figur rzut trajektorii na płaszczyznę pionową wpisuje się w prostokąt o wymiarach $4500 \times 1500 \mathrm{~m}$.

Analiza rzutu trajektorii lotu samolotu na płaszczyznę poziomą pokazuje , że rzut trajektorii lotu samolotu na płaszczyznę poziomą wpisuje się $\mathrm{W}$ prostokąt o wymiarach $4500 \mathrm{~m} \times 2500 \mathrm{~m}$. Przy tym wśród wymienionych figur na płaszczyźnie poziomej maksymalną powierzchnię ma figura obrót o $270^{\circ}-$ $2500 \mathrm{~m} \times 2600 \mathrm{~m}$.

Przedstawiony przykład pokazuje, że parametry zarejestrowane przez pokładowy system pozwalają dokonać analizy techniki pilotowania samolotu i wykryć zasadnicze odchylenia, które wpływają na bezpieczeństwo lotu i pozwalają ocenić jakość realizacji zadania lotniczego (lotu) przez pilota. 
W tabeli 3 zamieszczono analizę lotu wykonanego przez jednego pilota. Procedura może być powtórzona dla całej grupy szkolonych pilotów.

Tabela 3. Analiza porównawcza jakości wykonania figur pilotażowych na podstawie zarejestrowanych danych z pokładowych rejestratorów parametrów lotu

\begin{tabular}{|c|c|c|c|}
\hline L.p & Rodzaj figury & $\begin{array}{l}\text { Ograniczenia } \\
\text { wymagania }\end{array}$ & Uwagi \\
\hline 1. & Pętla & \multirow{10}{*}{$\begin{array}{l}\text { Model graficzny do } \\
\text { zadania. } \\
\mathrm{Vp}<300 \mathrm{~km} / \mathrm{h} \text {, } \\
\mathrm{n}_{\mathrm{y}}<\mathrm{w} \text { górnych } \\
\text { punktach figur w } \\
\text { przedziale } 4,5 \ldots . .5,5 .\end{array}$} & $\begin{array}{l}\text { Wejście do wykonania } \\
\text { figury niezgodne } \mathrm{z} \text { modelem } \\
\text { graficznym. }\end{array}$ \\
\hline 2. & Beczka & & bez uwag \\
\hline 3. & Pętla z przewrotem & & $\alpha>16^{\circ}$ \\
\hline 4. & Pętla & & $\alpha>16^{\circ}$ \\
\hline 5. & Pętla z przewrotem & & bez uwag \\
\hline 6. & Wiraż & & bez uwag \\
\hline 7. & Dzwon & & $\begin{array}{l}\text { Opracowano do lotów } \\
\text { pokazowych. }\end{array}$ \\
\hline 8. & $\begin{array}{l}\text { Lot odwrócony - } \\
\text { beczka - lot } \\
\text { odwrócony }\end{array}$ & & bez uwag \\
\hline 9. & Obrót o $270^{\circ}$ & & bez uwag \\
\hline 10. & Lot w strefie & & $\begin{array}{l}\text { Lot został wykonany w } \\
\text { strefie rozmiary której } \\
\text { wynosiły: } X=4500 \mathrm{~m} ; \\
\mathrm{H}=1500 \mathrm{~m} ; \mathrm{Z}=2600 \mathrm{~m} . .\end{array}$ \\
\hline
\end{tabular}

Do prowadzenia ww analiz i ocen niezbędne jest wsparcie informatyczne jako istotny element zarządzania procesem szkolenia lotniczego. Na rys. 18 przedstawiono schemat struktury danych wejściowych - wyjściowych Obiektywnej Kontroli Lotów lotnictwa wojskowego.

Na rys. 19. przedstawiono algorytm analizy lotu samolotu na podstawie zapisu jego parametrów przez pokładowy system rejestracji, który zawiera trzy etapy $\mathrm{z}$ propozycją wykorzystania funkcjonującego w lotnictwie wojskowym systemu informatycznego TURAWA,

- gromadzenie danych dotyczących samolotu, realizowanego zadania, załogi samolotu i inne;

- analizę zapisu informacji o locie;

- ocenę informacji, sporządzanie dokumentacji oraz jej archiwizowanie. 
Management of the training process of military pilots ...

Zarzadzanie procesem szkolenia pilotów wojskowych...

Gromadzenie danych i informacji w systemie będzie wykorzystane do dalszej analizy, w wyniku której powinny być identyfikowane problemy do rozwiązania $\mathrm{w}$ procesie szkolenia lotniczego.

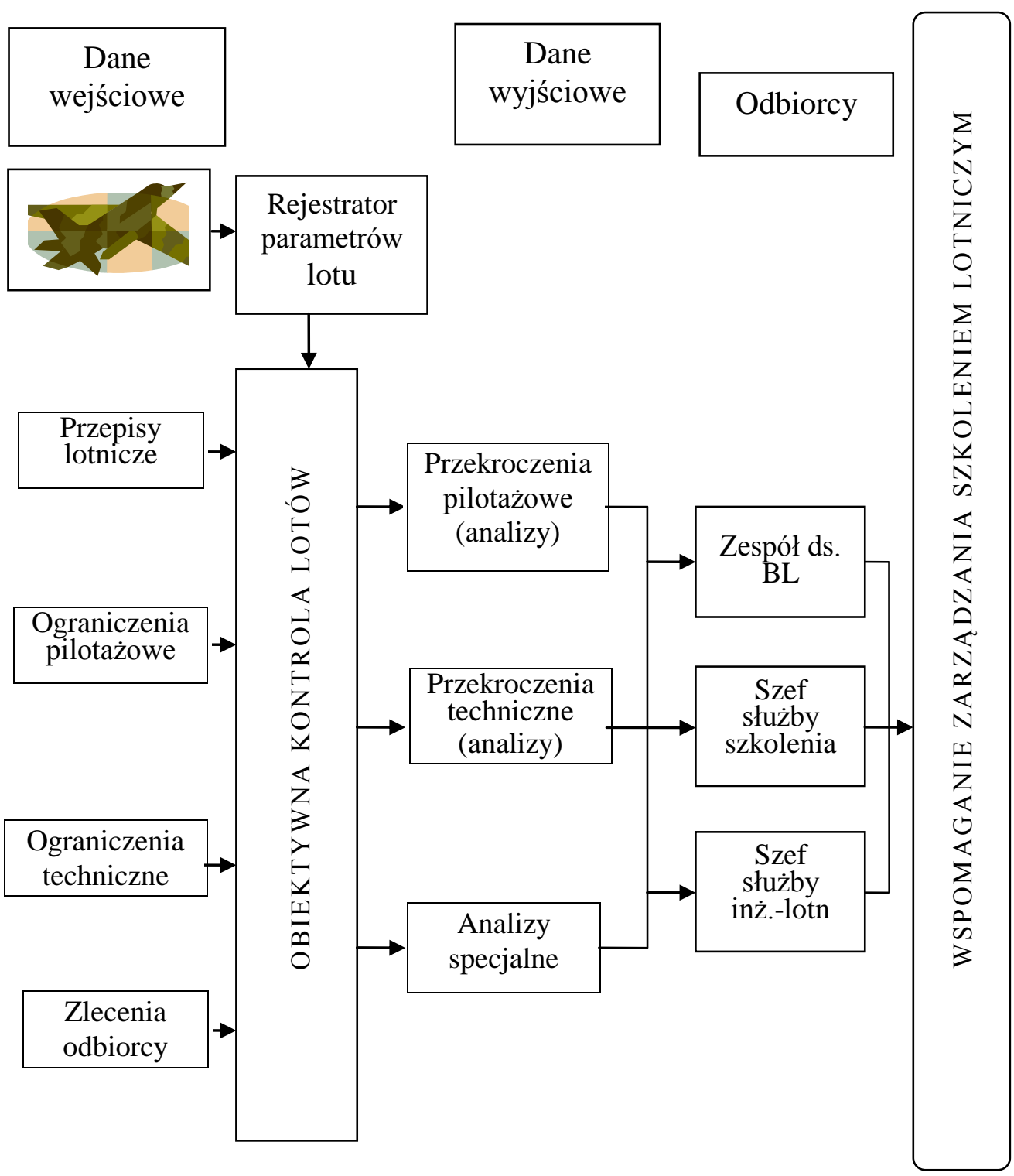

Rys. 19. Schemat struktury danych wejściowych - wyjściowych Obiektywnej Kontroli Lotów lotnictwa wojskowego 
Mariusz Zieja, Henryk Smolinski, Pawet Gołda

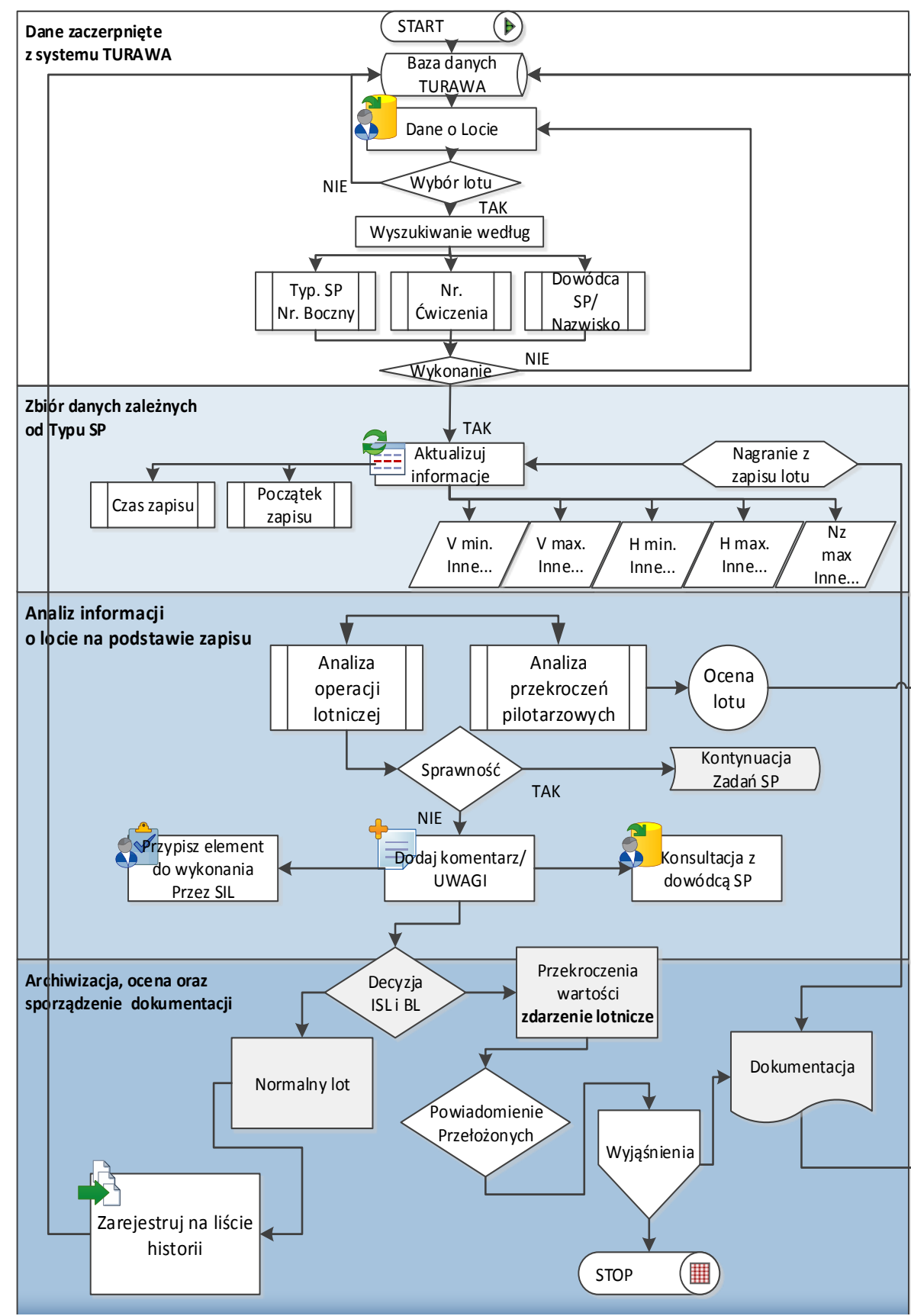

Rys.20. Algorytm analizy lotu samolotu z wykorzystaniem systemu informatycznego TURAWA 
Management of the training process of military pilots ...

Zarzadzanie procesem szkolenia pilotów wojskowych...

\section{Algorytm wspomagania procesu szkolenia pilotów wojskowych statków powietrznych}

Metodykę wspomagania procesu szkolenia pilotów wojskowych statków powietrznych można sformułować w postaci algorytmu (rys. 20).

Algorytm oparto o wyznaczenie podatności szkoleniowej systemu ,statek powietrzny-pilot" na podstawie subiektywnej oceny poprawności wykonywania figur pilotażu dokonywanej przez pilota-instruktora, która podlega weryfikacji na podstawie zapisów parametrów lotu w materiałach z obiektywnej kontroli lotów.

Algorytm rozpoczyna się od wytypowania grupy szkoleniowej oraz wybrania statku powietrznego przeznaczonego do szkolenia pilotów. Następnie dokonuje się oceny właściwości pilotów wytypowanych do realizacji zaplanowanego szkolenia. Równolegle przeprowadza się ocenę właściwości statku powietrznego przeznaczonego do szkolenia.

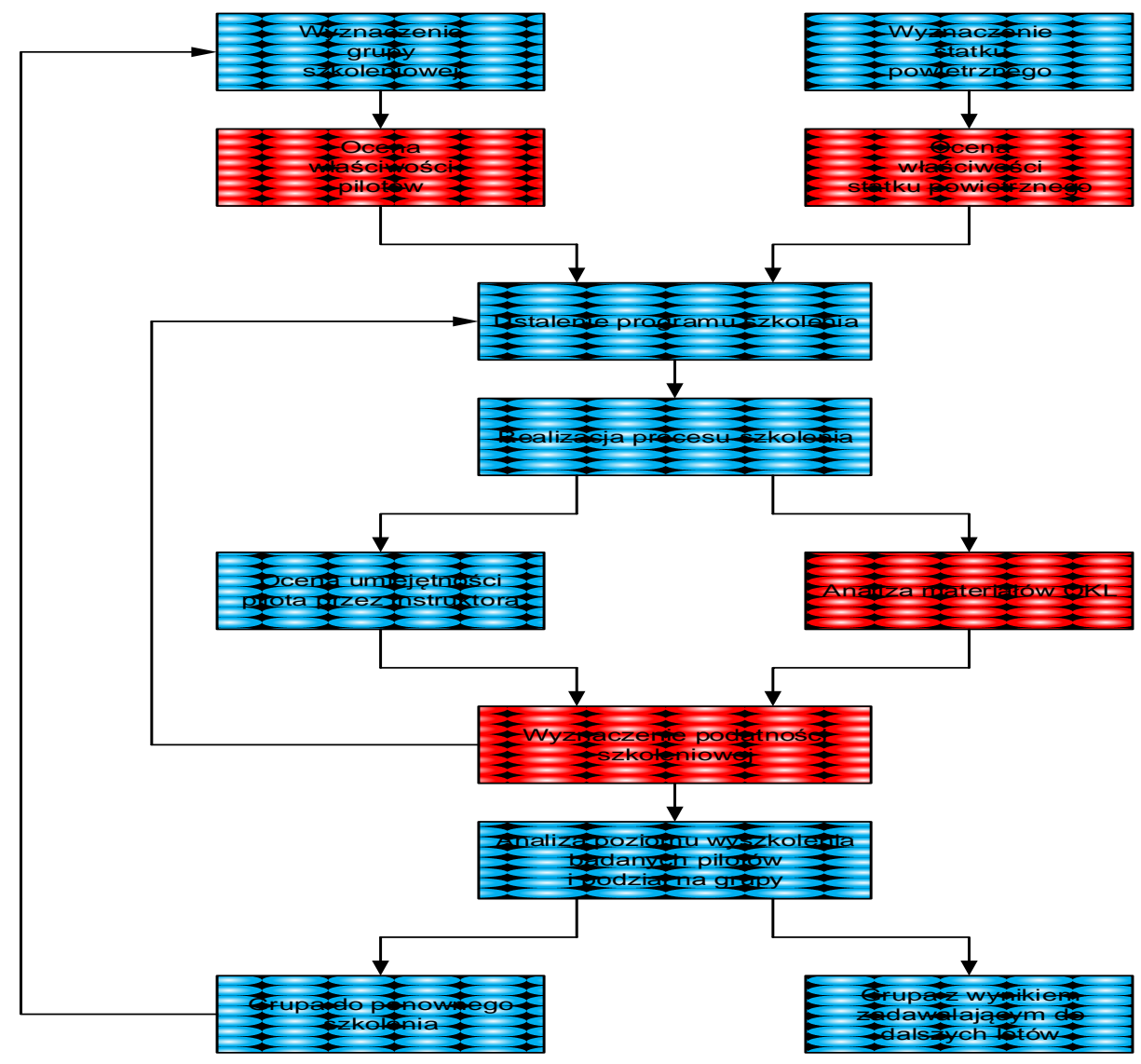

Rys. 21. Algorytm wspomagania procesu szkolenia pilotów wojskowych statków powietrznych [2] 
Kolejnym etapem zaproponowanego algorytmu jest ustalenie zestawu niezbędnych ćwiczeń przewidzianych programem szkolenia w celu osiągnięcia przez szkolonych pilotów wymaganych umiejętności.

W trakcie realizacji procesu szkolenia prawidłowość wykonywania poszczególnych figur pilotażowych jest oceniana przez pilota-instruktora. Subiektywna ocena poprawności wykonywania figur pilotażu dokonywana przez pilota-instruktora podlega weryfikacji na podstawie zapisanych parametrów w systemie obiektywnej kontroli lotów.

Po wyznaczeniu podatności szkoleniowej z uwzględnieniem przerw w ciągłości realizacji kolejnych etapów szkolenia dokonywana jest dla każdego pilota indywidualna modyfikacja programu szkolenia.

Po zakończeniu procesu szkolenia następuje analiza poziomu wyszkolenia badanych pilotów. Na podstawie uzyskanych wyników piloci zostają ponownie zakwalifikowani do odpowiednich grup szkoleniowych.

\section{Podsumowanie}

Zapisy informacji parametrycznych nagromadzone za pomocą pokładowych nośników rejestracji danych z lotu stanowią niezwykle ważne źródło wiadomości do analizy lotu samolotu. Zarejestrowane parametry umożliwiają przeanalizowanie stanu bezpieczeństwa lotów podczas wykonywania przez pilota figur pilotażowych. Gwarancją zadanego poziomu bezpieczeństwa lotów są ograniczenia eksploatacyjne przedstawione $\mathrm{w}$ instrukcji użytkowania w locie dla danego typu samolotu.

Model graficzny toru ruchu SP określony na podstawie zarejestrowanych parametrów lotu w rejestratorze pokładowym może być przydatny do oceny jakości wykonywania figur pilotażowych jako elementu szkolenia lotniczego.

Powyższe przykłady wskazują na niezbędność wykorzystania danych z pokładowych rejestratorów parametrów lotu oraz budowy odpowiedniego modułu w SI TURAWA do analizy lotu i wspomagania zarządzania bezpiecznym szkoleniem lotniczym.

\section{Literatura:}

[1] Babak, V.P. Caraczenko, V. O. Maksimow i inni. Pod redakcją Babaka V.P.: Bezpieka Awiacji: - Kijów, Technika, 2004.

[2] Bartosiewicz J., Stelmach A.: Problematyka przetwarzania parametrów uzyskanych $\mathrm{z}$ pokładowych rejestratorów eksploatacyjnych lotu. Prace Naukowe Politechniki Warszawskiej, z.103 2014.

[3] Dygnatowski S.: Badanie podatności szkoleniowej systemu statek powietrzny - pilot na przykładzie samolotu mig-29 Praca doktorska. Warszawa 2010.

[4] Instrukcja funkcjonowania systemu obiektywnej kontroli lotów w lotnictwie Sił Zbrojnych RP. Warszawa 2013.

[5] Instrukcja bezpieczeństwa lotów Lotnictwa Sił Zbrojnych Rzeczypospolitej Polskiej, MON 2015. 
Management of the training process of military pilots ...

Zarzadzanie procesem szkolenia pilotów wojskowych...

[6] Witkowski R.: System gromadzenia i przetwarzania danych z pokładowych rejestratorów parametrów lotu na przykładzie PLL "LOT" S.A.; stara.gorpol. $\mathrm{pl} /$ galeria/cz-skrzynki/referat.

[7] Zieja M., Smoliński H., Gołda P.: Proactive methods - new quality in aircraft flight safety management. Journal of KONBiN T4 (36) 2015.

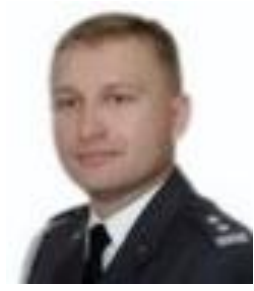

Mariusz Zieja, PhD. Eng. Polish Air Force, graduated from Military University of Technology in 2000. M.Sc. in Mechatronics specialized in Aircraft's Avionics. In 2008 achieved Ph.D. in Mechanical Engineering. Since 2010 Chief of Department in Air Force Institute of Technology (Udziat 33,3\%).

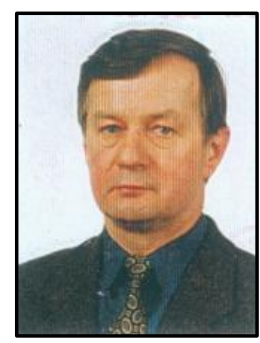

Henryk Smoliński, PhD. Eng. Polish Air Force, graduated from Military University of Technology in 1969. M.Sc. in Engines and Aircraft. In 1989 achieved Ph.D. in technical sciences in Construction and Operation of Machines. Since 1984 Assistant Professor in Air Force Institute of Technology (Udziat 33,3\%).

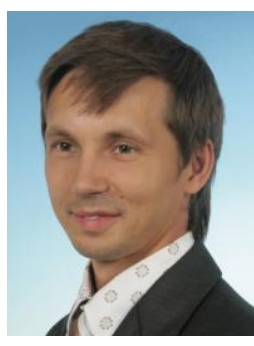

Pawel Golda, PhD. Eng. Polish Air Force, graduated from Warsaw University of Technology in 2008. M.Sc. in Air Traffic Control. In 2013 achieved Ph.D. in technical sciences in Construction and Operation of Machines. Since 2013 Assistant Professor in Air Force Institute of Technology (Udziat 33,3\%). 